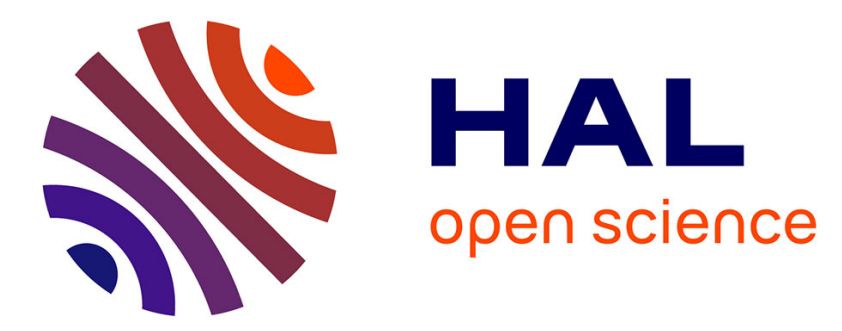

\title{
Fatty acid derivatised analogues of glucose-dependent insulinotropic polypeptide with improved antihyperglycaemic and insulinotropic properties
}

Barry D. Kerr, Nigel Irwin, Finbarr P.M. O'Harte, Clifford J. Bailey, Peter R. Flatt, Victor A. Gault

\section{To cite this version:}

Barry D. Kerr, Nigel Irwin, Finbarr P.M. O'Harte, Clifford J. Bailey, Peter R. Flatt, et al.. Fatty acid derivatised analogues of glucose-dependent insulinotropic polypeptide with improved antihyperglycaemic and insulinotropic properties. Biochemical Pharmacology, 2009, 78 (8), pp.1008. 10.1016/j.bcp.2009.05.037 . hal-00514597

\section{HAL Id: hal-00514597 https://hal.science/hal-00514597}

Submitted on 3 Sep 2010

HAL is a multi-disciplinary open access archive for the deposit and dissemination of scientific research documents, whether they are published or not. The documents may come from teaching and research institutions in France or abroad, or from public or private research centers.
L'archive ouverte pluridisciplinaire HAL, est destinée au dépôt et à la diffusion de documents scientifiques de niveau recherche, publiés ou non, émanant des établissements d'enseignement et de recherche français ou étrangers, des laboratoires publics ou privés. 


\section{Accepted Manuscript}

Title: Fatty acid derivatised analogues of glucose-dependent insulinotropic polypeptide with improved antihyperglycaemic and insulinotropic properties

Authors: Barry D. Kerr, Nigel Irwin, Finbarr P.M. O'Harte, Clifford J. Bailey, Peter R. Flatt, Victor A. Gault

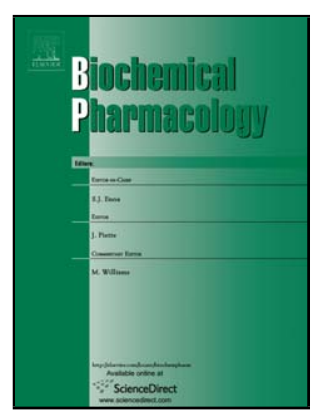

PII: S0006-2952(09)00449-3

DOI: doi:10.1016/j.bcp.2009.05.037

Reference: BCP 10210

To appear in: $\quad B C P$

Received date: 22-4-2009

Revised date: 28-5-2009

Accepted date: $\quad$ 29-5-2009

Please cite this article as: Kerr BD, Irwin N, O'Harte FPM, Bailey CJ, Flatt PR, Gault VA, Fatty acid derivatised analogues of glucose-dependent insulinotropic polypeptide with improved antihyperglycaemic and insulinotropic properties, Biochemical Pharmacology (2008), doi:10.1016/j.bcp.2009.05.037

This is a PDF file of an unedited manuscript that has been accepted for publication. As a service to our customers we are providing this early version of the manuscript. The manuscript will undergo copyediting, typesetting, and review of the resulting proof before it is published in its final form. Please note that during the production process errors may be discovered which could affect the content, and all legal disclaimers that apply to the journal pertain. 


\section{Fatty acid derivatised analogues of glucose-dependent insulinotropic polypeptide with improved antihyperglycaemic and insulinotropic properties}

Barry D. Kerr ${ }^{1}$, Nigel Irwin ${ }^{1}$, Finbarr P.M. O’Harte ${ }^{1}$, Clifford J. Bailey ${ }^{2}$, Peter R. Flatt ${ }^{1}$, Victor A. Gault $^{1 *}$

${ }^{1}$ The SAAD Centre for Pharmacy and Diabetes, School of Biomedical Sciences, University of Ulster, Coleraine BT52 1SA, Northern Ireland, UK and ${ }^{2}$ School of Life and Health Sciences, Aston University, Aston Triangle, Birmingham B4 7ET, UK

*Corresponding author: Victor A. Gault

Address: $\quad$ The SAAD Centre for Pharmacy and Diabetes,

School of Biomedical Sciences,

University of Ulster,

Cromore Road,

Coleraine BT52 1SA,

Northern Ireland, United Kingdom.

Email: va.gault@ulster.ac.uk.

Phone: ++44-(0)-28-70323322.

Fax: ++44-(0)-28-70324965. 


\begin{abstract}
C-terminal acylation of Lys $^{37}$ with myristic (MYR; tetradecanoic acid), palmitic (PAL; hexadecanoic acid) and stearic (octadecanoic acid) fatty acids with or without N-terminal acetylation was employed to develop long-acting analogues of the glucoregulatory hormone, glucose-dependent insulinotropic polypeptide (GIP). All GIP analogues exhibited resistance to dipeptidylpeptidase-IV (DPP-IV) and significantly improved in vitro cAMP production and insulin secretion. Administration of GIP analogues to $o b / o b$ mice significantly lowered plasma glucose - GIP(Lys ${ }^{37}$ MYR $), N$-AcGIP(Lys ${ }^{37}$ MYR $)$ and GIP(Lys $\left.{ }^{37} \mathrm{PAL}\right)$ increased plasma insulin concentrations. GIP( Lys $\left.^{37} \mathrm{MYR}\right)$ and $N$-AcGIP(Lys $\left.{ }^{37} \mathrm{MYR}\right)$ elicited protracted glucose-lowering effect when administered $24 \mathrm{~h}$ prior to an intraperitoneal glucose load. Daily administration of GIP(Lys ${ }^{37}$ MYR $)$ and $N$-AcGIP(Lys ${ }^{37}$ MYR $)$ to $o b / o b$ mice for 24 days decreased glucose and significantly improved plasma insulin, glucose tolerance and beta-cell glucose responsiveness. Insulin sensitivity, pancreatic insulin content and triglyceride levels were not changed. These data demonstrate that $\mathrm{C}$-terminal acylation particularly with myristic acid provides a class of stable, longer-acting forms of GIP for further evaluation in diabetes therapy.
\end{abstract}

Keywords: dipeptidylpeptidase-IV (DPP-IV); glucose-dependent insulinotropic polypeptide (GIP); GIP agonist; glucose homeostasis; insulin secretion. 


\section{Introduction}

Glucose-dependent insulinotropic polypeptide (GIP) is a gluco-regulatory hormone released from K-cells in response to feeding [1]. Despite initial characterisation based on its ability to inhibit gastric acid secretion, GIP, together with its sister hormone, glucagon-like peptide-1 (GLP-1), are now widely recognised as incretin hormones [2]. GIP and GLP-1 account for the total insulinotropic arm of the enteroinsular axis following meal ingestion, thereby reducing postprandial hyperglycaemia [3]. In contrast to currently used non-endogenous drugs, both GIP and GLP-1 elicit their potent insulinotropic actions in a glucose-dependent manner and as such avoid unwanted hypoglycaemic episodes. While GLP-1 based therapies, for example, exenatide, have now reached the market and are currently being prescribed to type 2 diabetic patients, the progression of GIP-based molecules has been somewhat hindered due to several fundamental limitations [4].

Firstly, insensitivity of the beta-cell to the insulin-releasing actions of GIP in type 2 diabetes has been noted $[5,6]$. However, it has emerged that rather than representing a GIP specific defect, this is a readily reversible phenomenon that can be rectified by improved diabetes control using other glucose-lowering drugs $[7,8]$. Thus combination therapy or use of modified GIP analogues can be expected to overcome any beta-cell insensitivity. Indeed the insulin-releasing and anti-diabetic potential of several amino-terminally modified GIP analogues have been demonstrated both in animal models and in preliminary studies in patients with type 2 diabetes [9]. Secondly, the pharmacokinetic profile of the native GIP hormone is severely compromised through rapid proteolytic degradation with the enzyme dipeptidylpeptidase-IV (DPP-IV; EC 3.4.14.5) generating the inactive major degradation product GIP(3-42) [10]. Thirdly, GIP and its associated metabolites are quickly eliminated and cleared from the body primarily via the kidney [11]. 
Furthermore, present appreciation of the role of circulating GIP in clinical diabetes and particularly fat deposition is far from complete [4].

These intrinsic limitations can be overcome through two different approaches including the application of specific DPP-IV inhibitors or the development of structurally modified GIP molecules which are resistant to the actions of DPP-IV [12]. Indeed, a range of structurally modified analogues of GIP have been developed, several of which have improved antihyperglycaemic and insulinotropic properties [4]. Recently, we have shown that GIP conjugated at the C-terminus with a mini-polyethylene glycol residue exhibited prolonged and enhanced biological actions in vivo [13]. However, another approach to avoid rapid renal filtration and clearance from the body is fatty acid derivatisation. Studies in our laboratory have shown that conjugating a C-16 fatty acid to the epsilon side-chain of Lys at position 37 resulted in significant benefits in both glucose-lowering and insulin-releasing actions [14-18]. Fatty acid derivatisation prolongs the biological half-life of GIP by masking the DPP-IV cleavage sight, but also facilitates binding to serum proteins thus reducing renal clearance $[15,16]$. Indeed, this approach has been employed in the development of several GLP-1 based therapies, for example, NN2211, which has been shown to elicit a prolonged pharmacodynamic profile (half-life $>12 \mathrm{~h}$ ) making it suitable for once-daily subcutaneous administration [19]. However, unlike GIP-based mimetics, prolonged administration of NN2211 and GLP-1 mimetics in general leads to gastrointestinal side-effects such as nausea due to a prolonged inhibitory effect on gastric emptying [9].

To date, only the biological efficacy of C-16 fatty acid derivatised GIP analogues have been reported [14-18]. Therefore, in the present study we characterised the effects of a range of fatty acid chain lengths (C-14, C-16 and C-18) with or without N-terminal acetylation on metabolic 
stability and biological actions. Stability of GIP analogues to DPP-IV degradation, as well as in vitro cAMP production and insulin secretion were examined. Furthermore, acute and prolonged actions of selected analogues were assessed in $o b / o b$ mice, a commonly employed animal model of type 2 diabetes displaying both beta-cell dysfunction and insulin resistance.

\section{Materials and methods}

2.1 Synthesis, purification and characterisation of GIP peptides

GIP peptides (see Table 1) were sequentially synthesised on an Applied BioSystems automated peptide synthesiser (ABI 432A Peptide Synthesiser; Warrington, Cheshire, UK) with a preloaded Fmoc-Gln(Trt)-Wang resin (typical loading 0.2-1.0 mmol/g; Sigma-Aldrich, Gillingham, Dorset, UK) using standard solid-phase Fmoc peptide chemistry [21]. Synthetic peptides were purified by semi-preparative HPLC followed by analytical HPLC and characterised using matrix-assisted laser desorption ionisation-time of flight (MALDI-TOF) mass spectrometry as described previously [16].

\subsection{Degradation of GIP peptides by DPP-IV}

GIP peptides were incubated at $37^{\circ} \mathrm{C}$ in $50 \mathrm{mM}$ triethanolamine- $\mathrm{HCl}(\mathrm{pH}$ 7.8) with purified porcine dipeptidylpeptidase-IV (5 mU; Sigma-Aldrich, UK) for 0, 2, 4, 8 and $24 \mathrm{~h}$ (no albumin was present in the incubation buffer). Enzymatic reactions were terminated by addition of $15 \mu l$ of $10 \%(\mathrm{v} / \mathrm{v}) \mathrm{TFA} /$ water. Reaction products were applied to a Vydac C-4 column $(4.6 \times 250 \mathrm{~mm}$; The Separations Group, Hesparia, California, USA) and intact peptide separated from the major degradation fragment GIP(3-42). Absorption was monitored at $206 \mathrm{~nm}$ using a SpectraSystem UV2000 detector (Thermoquest Ltd, Manchester, UK) and HPLC peak area data were used to calculate percentage intact peptide remaining at time points indicated during the incubation. 


\subsection{In vitro cAMP production and insulin secretion}

The effects of GIP peptides on the stimulation of cAMP production and insulin secretion were measured using clonal pancreatic BRIN-BD11 cells as described previously [22]. For cAMP studies, BRIN-BD11 cells were seeded (100,000 cells per well) into 96-well plates (Nunc, Roskilde, Denmark) and washed with HBS buffer before being incubated with various concentrations of GIP peptides in the presence of $1 \mathrm{mM}$ IBMX (Sigma-Aldrich, UK) for $20 \mathrm{~min}$ at $37^{\circ} \mathrm{C}$. After incubation, medium was removed and the cells lysed prior to measurement of cAMP using an HTS Immunoassay Kit (Millipore, Watford, UK). For insulin-release studies, BRIN-BD11 cells were seeded (100,000 cells per well) into 24 -well plates (Nunc, Roskilde, Denmark) and allowed to attach overnight at $37^{\circ} \mathrm{C}$. Following a $40 \mathrm{~min}$ pre-incubation $(1.1 \mathrm{mM}$ glucose; $\left.37^{\circ} \mathrm{C}\right)$, cells were incubated $\left(20 \mathrm{~min} ; 37^{\circ} \mathrm{C}\right)$ in the presence of $5.6 \mathrm{mM}$ glucose with a range of peptide concentrations (estimated albumin concentration $76.5 \mu \mathrm{M}$ ). After $20 \mathrm{~min}$ incubation, buffer was removed from each well and aliquots $(200 \mu \mathrm{l})$ stored at $-20^{\circ} \mathrm{C}$ prior to measurement of insulin using radioimmunoassay.

\subsection{Acute and persistent effects of GIP peptides on glucose-lowering and insulin release in} vivo

Obese diabetic $(o b / o b)$ mice and lean littermates from the Aston colony at 20-22 weeks of age were used to assess the in vivo biological properties of GIP peptides. The genetic background and characteristics of the colony used have been described in detail elsewhere [20]. Animals were age-matched, divided into groups and housed in an air-conditioned room at $22 \pm 2{ }^{\circ} \mathrm{C}$ with a $12 \mathrm{~h}$ light / $12 \mathrm{~h}$ dark cycle. Animals had free access to drinking water and normal laboratory chow (Trouw Nutrition, Cheshire, UK). All animal experiments were performed in accordance with the 
UK Animals (Scientific Procedures) Act 1986. No adverse effects were observed following administration of any of the treatments.

In a first series of experiments, overnight fasted normal mice received an intraperitoneal (ip) injection of saline $(0.9 \%(\mathrm{w} / \mathrm{v}) \mathrm{NaCl})$ or glucose $(18 \mathrm{mmol} / \mathrm{kg}$ body weight $)$ alone or in combination with GIP or $N$-AcGIP(Lys ${ }^{37} \mathrm{MYR}$ ) (each at $25 \mathrm{nmol} / \mathrm{kg}$ body weight). In a second set of experiments, overnight fasted $o b / o b$ mice received an ip injection of glucose alone (18 $\mathrm{mmol} / \mathrm{kg}$ body weight) or in combination with GIP peptides (each at $25 \mathrm{nmol} / \mathrm{kg}$ body weight). In a third series of experiments, glucose $(18 \mathrm{mmol} / \mathrm{kg}$ body weight; ip) was administered 24 and 48 $\mathrm{h}$ after injection of GIP peptides (each at $25 \mathrm{nmol} / \mathrm{kg}$ body weight) to $o b / o b$ mice. All test solutions were administered in a final volume of $8 \mathrm{ml} / \mathrm{kg}$ body weight.

\subsection{Sub-chronic effects of once daily administration of GIP peptides in ob/ob mice} Once-daily ip injections of $N$-AcGIP, GIP(Lys ${ }^{37}$ MYR) or $N$-AcGIP(Lys ${ }^{37} \mathrm{MYR}$ ) (each at 25 $\mathrm{nmol} / \mathrm{kg}$ body weight $)$ or saline vehicle $(0.9 \%(\mathrm{w} / \mathrm{v}) \mathrm{NaCl})$ were administered at 16:00 h over a 24-day treatment period. Food intake, body weight, non-fasting plasma glucose and insulin levels were monitored at intervals of $2-4$ days. Glucose tolerance $(18 \mathrm{mmol} / \mathrm{kg}$ body weight; ip) and insulin sensitivity (50 U/kg body weight; ip) tests were performed at the end of the study. At termination, blood for measurement of circulating triglycerides was taken and pancreatic tissues excised and processed for measurement of insulin following extraction with $5 \mathrm{ml} / \mathrm{g}$ ice-cold acid ethanol.

\subsection{Biochemical analyses}

Blood samples were collected from the cut tip on the tail vein of conscious mice into chilled fluoride/heparin glucose micro-centrifuge tubes (Sarstedt, Numbrecht, Germany) at the 
timepoints indicated in the figures. Samples were immediately centrifuged using a Beckman microcentrifuge (Beckman Instruments, Galway, Ireland) for $30 \mathrm{~s}$ at 13,000 x g. Plasma glucose was assayed by an automated glucose oxidase procedure [23] using a Beckman Glucose Analyser II (Beckman Instruments, Galway, Ireland). Plasma and pancreatic insulin was assayed by a modified dextran-coated charcoal radioimmunoassay as described previously [24]. Plasma triglyceride levels were measured using a Hitachi Automatic Analyser 912 (Boehringer Mannheim, Germany) as per manufacturer instructions.

\subsection{Statistical analysis}

Results are expressed as mean \pm SEM and data compared using the unpaired Student's $t$-test. Where appropriate, data were compared using repeated measures ANOVA or one-way ANOVA, followed by the Student-Newman-Keuls post-hoc test. Incremental area under the curve (AUC) analyses for plasma glucose and insulin were calculated using GraphPad Prism version 3.02. Groups of data were considered to be significantly different if $\mathrm{p}<0.05$.

\section{Results}

3.1. Structural characterisation and DPP-IV stability of GIP peptides.

Following solid-phase peptide synthesis and HPLC purification, the molecular mass of each peptide was determined using MALDI-TOF MS (Table 1). The molecular masses resolved for GIP peptides were: 5194.2 Da, GIP(Lys ${ }^{37}$ MYR); 5236.4 Da, N-AcGIP(Lys ${ }^{37}$ MYR); 5219.1 Da, GIP(Lys ${ }^{37}$ PAL); 5263.3 Da, N-AcGIP(Lys $\left.{ }^{37} \mathrm{PAL}\right) ; 5249.8$ Da, GIP(Lys $\left.{ }^{37} \mathrm{STE}\right)$; and $5292.8 \mathrm{Da}$, $N$-AcGIP(Lys ${ }^{37}$ STE $)$. Peptides were purified to $>95 \%$ purity and molecular masses correlated well with predicted theoretical molecular weights, thereby substantiating molecular identity. Also shown in Table 1, native GIP was rapidly hydrolysed in vitro by DPP-IV with an estimated half- 
life of $2.2 \mathrm{~h}$. In contrast, GIP analogues remained fully intact throughout the entire incubation period exhibiting half-lives of $>24 \mathrm{~h}$ (Table 1).

\subsection{In vitro cAMP production and insulin secretion}

Native GIP stimulated intracellular cAMP production in a concentration-dependent manner in BRIN-BD11 cells with an $\mathrm{EC}_{50}$ value of $0.70 \mathrm{nM}$. GIP analogues followed a similar pattern of concentration-dependent stimulation of cAMP production but exhibited improved $\mathrm{EC}_{50}$ values ( 0.07 to $0.27 \mathrm{nM}$; Table 1$)$. Consistent with effects on cAMP production, native GIP dosedependently stimulated insulin secretion (1.5 to 2.1 -fold; $\mathrm{p}<0.05)$ in BRIN-BD1 1 cells compared to control (5.6 mM glucose alone) incubations (Fig. 1). Similarly, GIP analogues dosedependently stimulated insulin secretion but with enhanced potency compared to control (2.8 to 4.0-fold; $\mathrm{p}<0.001)$ and to GIP (1.5 to 2.1 -fold; $\mathrm{p}<0.01$ to $\mathrm{p}<0.001)$. No significant differences were observed in insulin-releasing potency between GIP analogues.

\subsection{Acute effects of GIP peptides on glucose-lowering and insulin release in vivo.}

The acute effects of native GIP and a fatty acid modified GIP analogue, $N$-AcGIP(Lys $\left.{ }^{37} \mathrm{MYR}\right)$, on glucose-lowering and insulin release in the absence and presence of a glucose load are shown in Fig. 2. When native GIP and $N$-AcGIP(Lys ${ }^{37}$ MYR $)$ were administered in combination with saline vehicle to normal mice, no significant effects on plasma glucose and insulin concentrations were observed (Fig. 2A). However, in the presence of a glucose load (18 $\mathrm{mmol} / \mathrm{kg}$ body weight), $N$-AcGIP(Lys ${ }^{37}$ MYR) significantly lowered plasma glucose $(1.2$ to 1.7 -fold; $\mathrm{p}<0.05$ to $\mathrm{p}<0.01$ ) and increased plasma insulin concentrations $(1.3$ to 1.8 -fold; $p<0.05$ to $p<0.01)$ compared to GIP-treated animals (Fig. 2B).

Fig. 3 depicts the plasma glucose responses to ip administration of glucose alone or in combination with GIP peptides to $o b / o b$ mice. Administration of glucose alone resulted in a rapid 
and protracted rise in plasma glucose concentrations. The plasma glucose excursion following administration of native GIP was not significantly different to animals receiving glucose alone (control). However, administration of GIP analogues resulted in significantly reduced plasma glucose concentrations at all time points measured. This was corroborated by analysis of the area under the curve AUC (0-60 min) where GIP analogues exhibited significantly lower plasma glucose concentrations compared to glucose alone (1.2 to 1.4 -fold; $\mathrm{p}<0.05$ to $\mathrm{p}<0.001)$ and animals treated with GIP ( 1.2 to 1.4 -fold; $\mathrm{p}<0.05$ to $\mathrm{p}<0.001)$. The improved glucose-lowering action correlated with significantly elevated plasma insulin concentrations following administration of GIP(Lys ${ }^{37}$ MYR $), N$-AcGIP(Lys ${ }^{37}$ MYR $)$ and GIP(Lys $\left.{ }^{37} \mathrm{PAL}\right)$ compared to control $(1.2$ to 1.8 -fold; $\mathrm{p}<0.05$ to $\mathrm{p}<0.001)$ and GIP-treated animals $(1.2$ to 1.8 -fold; $\mathrm{p}<0.05$ to $\mathrm{p}<0.001$; Fig. 4). In contrast, $N$-AcGIP, $N$-AcGIP(Lys $\left.{ }^{37} \mathrm{PAL}\right), \mathrm{GIP}\left(\mathrm{Lys}^{37} \mathrm{STE}\right)$ and $N$ AcGIP(Lys ${ }^{37}$ STE) did not demonstrate significantly improved insulinotropic actions under conditions used (Fig. 4).

\subsection{Persistent effects of GIP peptides on glucose-lowering in $o b / o b$ mice}

As illustrated in Fig. 5, the glucose-lowering action of GIP(Lys $\left.{ }^{37} \mathrm{MYR}\right)$ and $\mathrm{N}$ AcGIP(Lys $\left.{ }^{37} \mathrm{MYR}\right)$ is clearly evident when administered $24 \mathrm{~h}$ prior to an ip glucose load. GIP(Lys ${ }^{37}$ MYR $)$ and $N$-AcGIP(Lys ${ }^{37}$ MYR $)$ significantly lowered plasma glucose at 15 and 60 min post injection compared to control $(1.2$ to 1.3 fold; $\mathrm{p}<0.01$ to $\mathrm{p}<0.001)$ and $N$-AcGIP treated mice ( 1.1 to 1.2 fold; $\mathrm{p}<0.05$ to $\mathrm{p}<0.01$ ). These results were supported by significantly decreased plasma glucose AUC values compared to control (1.2 fold; $\mathrm{p}<0.05)$ and $N$-AcGIP treated mice (1.1 to 1.2 fold; $\mathrm{p}<0.05$ to $\mathrm{p}<0.01)$. In contrast, GIP(Lys $\left.{ }^{37} \mathrm{PAL}\right), N$ AcGIP(Lys $\left.{ }^{37} \mathrm{PAL}\right), \mathrm{GIP}\left(\mathrm{Lys}{ }^{37} \mathrm{STE}\right)$ and $N$-AcGIP(Lys $\left.{ }^{37} \mathrm{STE}\right)$ demonstrated similar glycaemic profiles to control animals (Fig. 5). 
3.5. Effects of daily administration of $N$-AcGIP, GIP(Lys ${ }^{37}$ MYR $)$ and $N$-AcGIP(Lys ${ }^{37}$ MYR $)$ on bodyweight, food intake, non-fasting glucose and insulin concentrations in $o b / o b$ mice Daily administration of $N$-AcGIP, GIP(Lys ${ }^{37}$ MYR) and $N$-AcGIP(Lys ${ }^{37}$ MYR) for 24 days had no effect on body weight and food intake compared to saline-treated controls (Fig. 6A and 6B). Nonfasting plasma glucose concentrations were significantly lower in GIP(Lys $\left.{ }^{37} \mathrm{MYR}\right)$ (1.4 to 1.5fold; $\mathrm{p}<0.05$ to $\mathrm{p}<0.01)$ and $N$-AcGIP(Lys $\left.{ }^{37} \mathrm{MYR}\right)(1.5$ to 1.7 -fold; $\mathrm{p}<0.01$ to $\mathrm{p}<0.001)$ treated mice compared to saline-treated controls from Day 20 onwards (Fig. 6C). Furthermore, $\mathrm{N}$ AcGIP(Lys ${ }^{37}$ MYR $)$ treated mice exhibited significantly reduced plasma glucose concentrations (1.4-fold; $\mathrm{p}<0.05)$ compared to $N$-AcGIP treated animals. This reduced plasma glucose was correlated with significantly increased plasma insulin concentrations by Day 20 in GIP(Lys ${ }^{37}$ MYR) $(1.4$ to 1.9 -fold; $\mathrm{p}<0.01$ to $\mathrm{p}<0.001)$ and $N$-AcGIP(Lys $\left.{ }^{37} \mathrm{MYR}\right)(1.6$ to $2.2-$ fold; $\mathrm{p}<0.01$ to $\mathrm{p}<0.001$ ) treated mice compared to saline controls and $N$-AcGIP treated animals (Fig. 6D).

3.6. Effects of daily administration of $N$-AcGIP, GIP(Lys $\left.{ }^{37} \mathrm{MYR}\right)$ and $N$-AcGIP(Lys $\left.{ }^{37} \mathrm{MYR}\right)$ on glucose tolerance and plasma insulin response to glucose in $o b / o b$ mice As shown in Fig. 7A, daily administration of GIP(Lys ${ }^{37}$ MYR $)$ and $N$-AcGIP(Lys ${ }^{37}$ MYR $)$ for 24 days resulted in an improved glycaemic response to an ip glucose load with significantly decreased plasma glucose concentrations compared to saline control $(1.4$ to 1.5 fold; $p<0.001)$ and $N$-AcGIP $(1.3$ to 1.4 fold; $\mathrm{p}<0.05$ to $\mathrm{p}<0.01)$. The beneficial effects of GIP(Lys $\left.{ }^{37} \mathrm{MYR}\right)$ and $N$-AcGIP(Lys $\left.{ }^{37} \mathrm{MYR}\right)$ were particularly evident from plasma glucose AUC values $(0-60$ min), which was significantly reduced compared to saline control (1.4 and 1.5 fold, respectively; $\mathrm{p}<0.01)$ (Fig. 7A). Glucose-mediated plasma insulin concentrations were significantly elevated ( 1.5 to 4.4 fold; $\mathrm{p}<0.01$ to $\mathrm{p}<0.001$ ) for both GIP( $\left.\operatorname{Lys}^{37} \mathrm{MYR}\right)$ and $N$-AcGIP(Lys $\left.{ }^{37} \mathrm{MYR}\right)$ compared to both saline and $N$-AcGIP treated animals (Fig. 7B). 
3.7. Effects of daily administration of $N$-AcGIP, GIP(Lys ${ }^{37}$ MYR $)$ and $N$-AcGIP(Lys ${ }^{37}$ MYR $)$ on insulin sensitivity, pancreatic insulin content and circulating plasma triglyceride concentrations in $o b / o b$ mice

As shown in Table 2, plasma glucose AUC values were not significantly changed in any of the treatment groups following administration of exogenous insulin. Similarly, pancreatic insulin content and circulating plasma triglyceride concentrations were not significantly different between treated and control groups (Table 2).

\section{Discussion}

Renewed interest into the potential use of incretin hormones as antidiabetic therapies has emerged in recent years [4]. The glucose-dependent insulin secretion induced by GLP-1 and GIP offers benefits over currently used single action, non-endogenous drugs that stimulate insulin secretion at any glucose concentration. Lack of effect of GIP on gastric emptying offers a potential advantage compared with therapies based on GLP-1 [9]. However, circulating GIP is rapidly hydrolysed by the ubiquitous enzyme DPP-IV and efficiently cleared from the body through renal filtration [11]. The potential of C-16 fatty acid (PAL) conjugated GIP analogues has been explored recently with $N$-AcGIP( Lys $\left.^{37} \mathrm{PAL}\right)$ appearing to be the most promising analogue $[15,16]$. The present study examined further the effect of fatty acid chain length, with or without N-terminal acetylation, on biological efficacy through assessing in vitro and in vivo antihyperglycaemic and insulinotropic properties.

Following confirmation of successful Fmoc peptide synthesis by MALDI-TOF MS, the susceptibility of GIP peptides to DPP-IV was examined. Unlike the native hormone which displayed an in vitro biological half life of approximately $2.2 \mathrm{~h}$, GIP analogues remained fully 
intact throughout the entire $24 \mathrm{~h}$ incubation (half-lives $>24 \mathrm{~h}$ ). While the conditions used for the DPP-IV assay in the present study were not able to discriminate $t_{1 / 2}$ between analogues, more detailed examination of SAR would be of interest in future studies. However, despite the probability of peptide adsorption during the longer incubation periods, this confirms in vitro DPP-IV resistance of each GIP analogue tested. It therefore appears that N-terminal acetylation and the addition of $\mathrm{C} 14-\mathrm{C} 18$ fatty acid residue close to the $\mathrm{C}$-terminal region inhibits the action of DPP-IV, perhaps by disrupting the GIP hydro-affinity for the enzyme, as reported previously [16]. Interestingly, C14-C18 acylation without additional N-terminal acetylation also resulted in stable GIP analogues most likely due to steric hindrance.

Broadly similar to previous studies, native GIP concentration-dependently stimulated cAMP production with an $\mathrm{EC}_{50}$ value of $0.70 \mathrm{nM}$ [16]. Likewise, GIP analogues stimulated cAMP production in a concentration-dependent manner. However, analogues demonstrated up to a 10fold reduction in $\mathrm{EC}_{50}$ value relative to GIP. This suggests enhanced potency at the GIP receptor, and is indicative of preserved receptor affinity with improved activation of the adenylate cyclase transduction pathway. This increased potency is corroborated by GIP analogues significantly inducing concentration-dependant stepwise increases in insulin secretion from BRIN-BD11 cells. At the highest concentrations, GIP analogues evoked a notable improvement in insulin secretion which quite likely reflects both increased potency and enhanced biological half-life [16]. Since no significant degradation of GIP occurred during these in vitro incubations, these data suggest that the combination of increased DPP-IV resistance and improved biological potency at the cellular level should provide analogues with greatly enhanced activity in vivo.

To assess the antihyperglycaemic and insulinotropic effects of GIP analogues in vivo, we employed the $o b / o b$ mouse model from the Aston colony [20]. On this genetic background, $o b / o b$ 
mice present with hyperphagia, marked obesity, moderate hyperglycaemia and severe hyperinsulinaemia representing a very robust model of type 2 diabetes and obesity. As in previous studies, native GIP had no significant effect on plasma glucose or the insulin response following an intraperitoneal glucose load $[16,17]$ due to its short biological half-life following degradation by DPP-IV and efficient renal clearance. In contrast, all GIP analogues demonstrated improved glucose-lowering actions. However, only GIP(Lys $\left.{ }^{37} \mathrm{MYR}\right), N$-AcGIP(Lys $\left.{ }^{37} \mathrm{MYR}\right)$ and GIP(Lys $\left.{ }^{37} \mathrm{PAL}\right)$ appeared substantially more effective and longer-acting in stimulating insulin release. Reasons underlying these differences are unclear but likely reflect alterations in beta-cell stimulation possibly due to changes in effective concentrations as a result of protein binding and various non beta-cell and extrapancreatic actions $[4,16]$. Nevertheless, the magnitude of improvements in the glycaemic and insulinotropic responses of GIP(Lys $\left.{ }^{37} \mathrm{MYR}\right), N$ AcGIP(Lys $\left.{ }^{37} \mathrm{MYR}\right)$ and GIP( $\left(\mathrm{Lys}^{37} \mathrm{PAL}\right)$ is notable given the severe insulin resistance of the $o b / o b$ syndrome [20]. Importantly, when $N$-AcGIP(Lys $\left.{ }^{37} \mathrm{MYR}\right)$ was injected acutely together with saline in normal mice, no significant effects on glucose-lowering or insulin release were observed. However, when co-injected with a glucose load $N$-AcGIP(Lys ${ }^{37}$ MYR $)$ significantly lowered plasma glucose and increased plasma insulin concentrations, thus demonstrating a potent glucose-dependent effect. From these acute studies it appears that DPP-IV resistant analogues of GIP can substantially overcome any possible defects in responsiveness of GIP in type 2 diabetes.

The longer-acting glucose-lowering effects of GIP analogues were assessed through an intraperitoneal glucose tolerance in animals $24 \mathrm{~h}$ following peptide administration. Interestingly, only GIP(Lys $\left.{ }^{37} \mathrm{MYR}\right)$ and $N$-AcGIP(Lys $\left.{ }^{37} \mathrm{MYR}\right)$ elicited a persistent improvement in glycaemic control $24 \mathrm{~h}$ after administration. The reason why a persistent glucose-lowering effect was not observed with the palmitic acid GIP analogues is unclear $[15,16]$, but could be due to differences in the conformation or activity of the analogue. The prolonged action of GIP( $\left.\operatorname{Lys}^{37} \mathrm{MYR}\right)$ and $N$ - 
AcGIP(Lys ${ }^{37}$ MYR $)$ suggests a much more extended plasma half-life, reflecting an enhanced ability of this shorter C-14 chain to structurally orientate and bind more strongly to serum proteins preventing kidney filtration [11]. The development of a specific assay to assess plasma levels of these fatty acid GIP analogues would be necessary to provide more precise details of these kinetics.

Results of these acute in vivo studies provided a strong basis for the subsequent 24 day study. Daily intraperitoneal injection of $N$-AcGIP, GIP(Lys ${ }^{37}$ MYR $)$ and $N$-AcGIP(Lys ${ }^{37}$ MYR $)$ over this time had no apparent adverse or toxic effects. Bodyweight and food intake were similar to salinetreated controls confirming previous findings [15]. Importantly, GIP(Lys $\left.{ }^{37} \mathrm{MYR}\right)$ and $N$ AcGIP(Lys ${ }^{37}$ MYR), and to a lesser effect, $N$-AcGIP, significantly reduced plasma glucose levels from day 20 of the study, accompanied by significantly elevated plasma insulin levels. Glucose tolerance was markedly improved in animals treated with GIP(Lys ${ }^{37}$ MYR $)$ and $N$ AcGIP(Lys ${ }^{37}$ MYR $)$ and this was accompanied by significantly increased plasma insulin concentrations. This confirms the long-acting insulinotropic effects of these analogues and their ability to overcome the severe beta-cell defect in this model. Improvement in glucose homeostasis was independent of any change in insulin sensitivity which is in agreement with previous findings [14-18]. There were no observed changes in pancreatic insulin content or plasma triglyceride levels although a more prolonged treatment period may be necessary to see improvements in these parameters.

In conclusion, this study demonstrated that fatty acid derivatisation at position Lys ${ }^{37}$, with or without N-terminal acetylation confers DPP-IV resistance and improved biological efficacy during in vitro and acute in vivo studies. Furthermore, derivatisation with a C-14 fatty acid offered a more protracted and markedly improved biological function over C-16 and C-18 fatty 
acid counterparts. These data represent an important step in the progression of fatty acid derivatised GIP analogues as a potential therapy for type 2 diabetes. Further studies are required to answer whether or not these analogues will be useful in human diabetes treatment.

\section{Acknowledgements}

These studies were supported by a Project Grant from Diabetes UK, the SAAD Trading and Contracting Company and University of Ulster Strategic Research Funding. The authors wish to thank Brett Greer and Pat Harriott (Queen's University of Belfast, UK) for peptide synthesis and Jenny Pineda and James Doherty for assistance in peptide purification.

\section{References}

[1] Brown JC. Enteroinsular axis. In Gut Peptides: Biochemistry and Physiology; Dockray, GJ, Walsh, JH, Eds; Raven Press: New York, 1994;pp 765-784.

[2] Holst JJ, Vilsbøll T, Deacon CF. The incretin system and its role in type 2 diabetes mellitus. Mol Cell Endocrinol 2009;297:127-136.

[3] Creutzfeldt W. The entero-insular axis in type 2 diabetes - incretins as therapeutic agents. Exp Clin Endocrinol Diabetes 2001;109:288-303.

[4] Irwin N, Flatt PR, Gault VA. GIP-based therapeutics for diabetes and obesity. Curr Chem Bio 2008;2:61-68.

[5] Vilsbøll T, Knop FK, Krarup T, Johansen A, Madsbad S, Laren S, et al. The pathophysiology of diabetes involves a defective amplification of late phase insulin response to glucose by glucose-dependent insulinotropic polypeptide-regardless of etiology and phenotype. J Clin Endocrinol Metab 2003;88:4897-4903. 
[6] Nauck MA, Heimesaat MM, Ørskov C, Holst JJ, Ebert R, Creutzfeldt W. Preserved incretin activity of glucagon-like peptide 1 [7-36 amide] but not of synthetic human gastric inhibitory polypeptide in patients with type 2 diabetes mellitus. J Clin Invest 1993;91:301-307.

[7] Piteau S, Oliver A, Kim SJ, Winter K, Pospisilik JA, Lynn F, et al. Reversal of islet GIP receptor down-regulation and resistance to GIP by reducing hyperglycaemia in Zucker rat. Biochem Biophys Res Commun 2007;362:1007-1012.

[8] Aaboe K, Knop FK, Vilsbøll T, Madsbad S, Deacon CF, Holst JJ, et al. Acute administration of a sulfonylurea compound restores the insulinotropic effect of glucosedependent insulinotropic polypeptide in patients with type 2 diabetes. Diabetologia 2007;50(S1):S248 [Abstract].

[9] Green BD, Irwin N, Gault VA, O'Harte FPM, Flatt PR. Development and therapeutic potential of incretin hormone analogues for type 2 diabetes. Br J Diabetes Vas Dis 2005;5:134-140.

[10] Kieffer TJ, McIntosh CH, Pederson RA. Degradation of glucose-dependant insulinotropic polypeptide and truncated glucagon-like peptide 1 in vitro and in vivo by dipeptidyl peptidase IV. Endocrinology 1995;136:3585-3596.

[11] Meier JJ, Nauck MA, Kranz D, Holst JJ, Deacon CF, Gaeckler D, et al. Secretion, degradation, and elimination of glucagon-like peptide 1 and gastric inhibitory polypeptide in patients with chronic renal insufficiency and healthy control subjects. Diabetes 2004;53:654-662.

[12] Flatt PR, Green BD, Bailey CJ. Dipeptidyl peptidase IV (DPP IV) and related molecules in type 2 diabetes. Front Biosci 2008;13:3648-3660. 
[13] Gault VA, Kerr BD, Irwin N, Flatt PR. C-terminal mini-PEGylation of glucose-dependent insulinotropic polypeptide exhibits metabolic stability and improved glucose homeostasis in dietary-induced diabetes. Biochem Pharmacol 2008;75:2325-2333.

[14] Irwin N, Green BD, Gault VA, Greer B, Harriott P, Bailey CJ, et al. Degradation, insulin secretion and antihyperglycemic actions of two palmitate-dervitized N-terminal proglutamyl analogues of glucose dependent insulinotropic polypeptide. J Med Chem $2005 ; 48: 1244-1250$.

[15] Irwin N, Green BD, Mooney MH, Greer B, Harriott P, Bailey CJ, et al. A novel, longacting agonist of glucose-dependent insulinotropic polypeptide suitable for once-daily administration in type 2 diabetes. J Pharmacol Exp Ther 2005;314:1187-1194.

[16] Irwin N, Gault VA, Green BD, Greer B, Harriot P, Bailey CJ, et al. Antidiabetic potential of two novel fatty acid derivatised, N-terminally modified analogues of glucosedependent insulinotropic polypeptide (GIP): N-AcGIP(LysPAL ${ }^{16}$ ) and NAcGIP(LysPAL ${ }^{37}$ ). Biol Chem 2005;386:679-687.

[17] Irwin N, O’Harte FPM, Gault VA, Green BD, Greer B, Harriott P, et al. GIP(Lys16PAL) and GIP(Lys37PAL): novel long-acting acylated analogues of glucose-dependent insulinotropic polypeptide with improved antidiabetic potential. J Med Chem 2006;49:1047-1054.

[18] Irwin N, Clarke GC, Green BD, Greer B, Harriott P, Gault VA, et al. Evaluation of the antidiabetic activity of DPP IV resistant N-terminally modified versus mid-chain acylated analogues of glucose-dependent insulinotropic polypeptide. Biochem Pharmacol 2006;72:719-728.

[19] Vilsbøll T, Brock B, Perrild H, Levin K, Lervang HH, Kølendorf K, et al. Liraglutide, a once-daily human GLP-1 analogue, improves pancreatic B-cell function and arginine- 
stimulated insulin secretion during hyperglycaemia in patients with Type 2 diabetes mellitus. Diabet Med 2008;25:152-156.

[20] Bailey CJ, Flatt PR. Influence of genetic background and age on the expression of the obese hyperglycaemic syndrome in Aston ob/ob mice. Int J Obes 1982;6:11-21.

[21] Fields GB, Noble RL. Solid-phase peptide synthesis utilizing 9-florenylmethoxycarbonyl amino acids. Int J Pept Prot Res 1990;35:161-214.

[22] McClenaghan NH, Barnett CR, Ah-Sing E, Abdel-Wahab YH, O'Harte FPM, Yoon TW, et al. Characterization of a novel glucose-responsive insulin-secreting cell line, BRINBD11, produced by electro-fusion. Diabetes 1996;45:1132-1140.

[23] Stevens JF. Determination of glucose by an automated analyser. Clin Chem Acta 1971;32:199-201.

[24] Flatt PR, Bailey CJ. Abnormal plasma glucose and insulin responses in heterozygous lean (ob/+) mice. Diabetologia 1981;20:573-577. 
Table 1 In vitro characteristics of GIP peptides with and without $\mathrm{N}$-terminal acetylation

\begin{tabular}{|l|c|c|c|c}
\hline \multirow{2}{*}{ Peptide } & \multicolumn{2}{|c|}{ MALDI-TOF MS } & $\begin{array}{c}\text { Estimated } \\
\text { half-life (h) }\end{array}$ & $\begin{array}{c}\text { cAMP EC } \\
\text { (nM) }\end{array}$ \\
\cline { 2 - 3 } & $\begin{array}{c}\text { Theoretical } \\
(\mathbf{D a})\end{array}$ & $\begin{array}{c}\text { Experimental } \\
\text { (Da) }\end{array}$ & & \\
\hline GIP & 4982.4 & 4982.2 & 2.2 & $0.70 \pm 0.40$ \\
\hline$N$-AcGIP & 5023.0 & 5022.2 & $>24$ & $0.17 \pm 0.01$ \\
\hline GIP(Lys ${ }^{37}$ MYR) & 5192.8 & 5194.2 & $>24$ & $0.27 \pm 0.03$ \\
\hline$N$-AcGIP(Lys ${ }^{37}$ MYR) & 5235.8 & 5236.4 & $>24$ & $0.07 \pm 0.01$ \\
\hline GIP(Lys ${ }^{37}$ PAL) & 5218.0 & 5219.1 & $>24$ & $0.07 \pm 0.03$ \\
\hline$N$-AcGIP(Lys $\left.{ }^{37} \mathrm{PAL}\right)$ & 5264.0 & 5263.3 & $>24$ & $0.11 \pm 0.03$ \\
\hline GIP(Lys ${ }^{37}$ STE) & 5247.0 & 5249.8 & $>24$ & $0.08 \pm 0.02$ \\
\hline$N$-AcGIP(Lys ${ }^{37}$ STE) & 5290.0 & 5292.8 & $>24$ & $0.09 \pm 0.01$ \\
\hline
\end{tabular}

MALDI-TOF MS: purified peptide samples were mixed with $\alpha$-cyano- 4 hydroxycinnamic acid, applied to the sample plate of a Voyager-DE BioSpectrometry Workstation and mass-to-charge $(\mathrm{m} / \mathrm{z})$ ratio $v s$ relative peak intensity recorded. DPP-IV degradation: resistance of GIP and GIP analogues to degradation by DPP-IV was measured $(n=4)$ following $0,2,4,8$ and $24 \mathrm{~h}$ incubations. Reaction products were subsequently analysed by HPLC and degradation calculated as a percentage of intact peptide relative to the major degradation fragment, GIP(3-42). cAMP production: $\mathrm{EC}_{50}$ values calculated are expressed as mean $\pm \mathrm{SEM}$ of at least 3 independent experiments. 
Table 2 Effects of daily administration of $N$-AcGIP, GIP(Lys $\left.{ }^{37} \mathrm{MYR}\right)$ and $N$-GIP(Lys $\left.{ }^{37} \mathrm{MYR}\right)$ on insulin sensitivity, insulin content and circulating triglycerides in $o b / o b$ mice.

\begin{tabular}{|l|c|c|c|}
\hline Peptide treatment & $\begin{array}{c}\text { Insulin sensitivity } \\
\text { (glucose AUC) }\end{array}$ & $\begin{array}{c}\text { Insulin content (ng/g } \\
\text { tissue) }\end{array}$ & Triglycerides (ng/dl) \\
\hline Saline vehicle & $898.7 \pm 80.0$ & $3.9 \pm 0.4$ & $2.2 \pm 0.2$ \\
\hline$N$-AcGIP & $997.5 \pm 72.6$ & $4.0 \pm 0.3$ & $2.1 \pm 0.3$ \\
\hline GIP(Lys ${ }^{37}$ MYR) & $912.0 \pm 34.2$ & $4.0 \pm 0.4$ & $2.4 \pm 0.3$ \\
\hline$N$-GIP(Lys ${ }^{37}$ MYR) & $902.3 \pm 95.9$ & $4.5 \pm 0.5$ & $2.1 \pm 0.2$ \\
\hline
\end{tabular}

Insulin sensitivity: exogenous insulin ( $50 \mathrm{U} / \mathrm{kg}$ body weight; ip) was administered after daily treatment with GIP peptides ( $25 \mathrm{nmol} / \mathrm{kg}$ body weight) for 24 days. Plasma glucose AUC values for 0-60 min post injection were calculated. Pancreatic insulin content and circulating triglycerides: parameters were measured after daily treatment with GIP peptides for 24 days. Data are expressed as mean \pm SEM for 8 mice. 


\section{Legends to Figures}

Fig. 1 - Effects of GIP peptides on insulin secretion. Various concentrations of GIP peptides were incubated with BRIN-BD11 cells in the presence of $5.6 \mathrm{mM}$ glucose for $20 \mathrm{~min}(\mathrm{n}=8)$ and insulin release measured using RIA. Data are expressed as mean \pm SEM. ${ }^{*} \mathrm{p}<0.05,{ }^{*} \mathrm{p}<0.01,{ }^{* * *} \mathrm{p}<$ 0.001 compared to glucose alone. ${ }^{\Delta} \mathrm{p}<0.05,{ }^{\Delta \Delta} \mathrm{p}<0.01,{ }^{\Delta \Delta \Delta} \mathrm{p}<0.001$ compared with GIP at the same concentration.

Fig. 2 - Acute effects of GIP and N-AcGIP(Lys ${ }^{37}$ MYR) on glucose-lowering and glucoseinduced insulin release in normal mice. (A) Plasma glucose and insulin concentrations were measured prior to and after ip administration of saline alone $(0.9 \%(\mathrm{w} / \mathrm{v}) \mathrm{NaCl})$ or in combination with GIP or $N$-AcGIP(Lys ${ }^{37}$ MYR) (each at $25 \mathrm{nmol} / \mathrm{kg}$ body weight). (B) Plasma glucose and insulin concentrations were measured prior to and after ip administration of glucose alone (18 $\mathrm{mmol} / \mathrm{kg}$ bw) or in combination with GIP or $N$-AcGIP(Lys ${ }^{37} \mathrm{MYR}$ ) (each at $25 \mathrm{nmol} / \mathrm{kg}$ body weight). Plasma glucose and insulin AUC values for 0-60 min post injection are also included. Data are expressed as mean \pm SEM for 6 mice. ${ }^{*} \mathrm{p}<0.05,{ }^{*} \mathrm{p}<0.01,{ }^{* * *} \mathrm{p}<0.001$ compared to glucose alone. ${ }^{\Delta} \mathrm{p}<0.05,{ }^{\Delta \Delta} \mathrm{p}<0.01,{ }^{\Delta \Delta \Delta} \mathrm{p}<0.001$ compared with GIP treated mice. $\square$, control; $\circ$, GIP; $\nabla, N$-AcGIP(Lys ${ }^{37}$ MYR).

Fig. 3 - Acute effects of GIP peptides on glucose-lowering in $o b / o b$ mice. Plasma glucose concentrations were measured prior to and after ip administration of glucose alone $(18 \mathrm{mmol} / \mathrm{kg}$ body weight) or in combination with GIP peptides ( $25 \mathrm{nmol} / \mathrm{kg}$ body weight). Plasma glucose AUC values for 0-60 min post injection are also included. Data are expressed as mean \pm SEM for 6 mice. ${ }^{*} \mathrm{p}<0.05,{ }^{* *} \mathrm{p}<0.01,{ }^{* * *} \mathrm{p}<0.001$ compared to glucose alone. ${ }^{\Delta} \mathrm{p}<0.05,{ }^{\Delta \Delta} \mathrm{p}<0.01$ ${ }^{\Delta \Delta \Delta} \mathrm{p}<0.001$ compared with GIP treated mice. $\square$, control;, , GIP; $\boldsymbol{\Delta}, N$-AcGIP; 
GIP(Lys ${ }^{37}$ MYR); $\nabla, N$-AcGIP(Lys ${ }^{37}$ MYR); $\nabla$, GIP(Lys ${ }^{37}$ PAL); $\diamond, N$-AcGIP(Lys ${ }^{37}$ PAL); • GIP(Lys $\left.{ }^{37} \mathrm{STE}\right) ; \Delta, N$-AcGIP(Lys $\left.{ }^{37} \mathrm{STE}\right)$.

Fig. 4 - Acute effects of GIP peptides on insulin release in $o b / o b$ mice. Plasma insulin concentrations were measured prior to and after ip administration of glucose alone $(18 \mathrm{mmol} / \mathrm{kg}$ body weight $)$ or in combination with GIP peptides ( $25 \mathrm{nmol} / \mathrm{kg}$ body weight). Plasma insulin AUC values for 0-60 min post injection are also included. Data are expressed as mean $\pm \mathrm{SEM}$ for 6 mice. ${ }^{*} \mathrm{p}<0.05, * * \mathrm{p}<0.01, * * * \mathrm{p}<0.001$ compared to glucose alone. ${ }^{\Delta} \mathrm{p}<0.05,{ }^{\Delta \Delta} \mathrm{p}<0.01$ ${ }^{\Delta \Delta \Delta} \mathrm{p}<0.001$ compared with GIP treated mice. $\square$, control; ○, GIP; $\boldsymbol{\Delta}, N$-AcGIP;

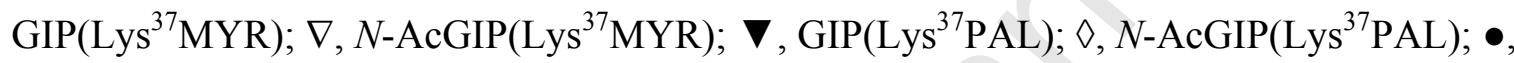
GIP(Lys $\left.{ }^{37} \mathrm{STE}\right) ; \Delta, N$-AcGIP(Lys $\left.{ }^{37} \mathrm{STE}\right)$.

Fig. 5 - Persistence of glucose-lowering effects of GIP peptides in $o b / o b$ mice. Plasma glucose concentrations were measured prior to and after ip administration of glucose alone $(18 \mathrm{mmol} / \mathrm{kg}$ body weight) in animals injected $24 \mathrm{~h}$ previously with GIP peptides $(25 \mathrm{nmol} / \mathrm{kg}$ body weight). Plasma glucose AUC values for 0-60 min post injection are also included. Data are expressed as mean \pm SEM for 6 mice. ${ }^{*} \mathrm{p}<0.05,{ }^{* *} \mathrm{p}<0.01, * * * \mathrm{p}<0.001$ compared to glucose alone. ${ }^{\Delta} \mathrm{p}<$ $0.05,{ }^{\Delta \Delta} \mathrm{p}<0.01$ compared with $N$-AcGIP treated mice. $\square$, control; $\circ$, GIP; $\boldsymbol{\Delta}, N$-AcGIP; $\mathbf{\square}$, GIP(Lys ${ }^{37}$ MYR $) ; \square, N$-AcGIP(Lys ${ }^{37}$ MYR $) ; \boldsymbol{\nabla}$, GIP(Lys $\left.{ }^{37} \mathrm{PAL}\right) ; \diamond, N$-AcGIP(Lys $\left.{ }^{37} \mathrm{PAL}\right) ; \bullet$ GIP(Lys $\left.{ }^{37} \mathrm{STE}\right) ; \Delta, N$-AcGIP(Lys $\left.{ }^{37} \mathrm{STE}\right)$.

Fig. 6 - Effects of daily administration of $N$-AcGIP, GIP(Lys $\left.{ }^{37} \mathrm{MYR}\right)$ and $N$-AcGIP(Lys $\left.{ }^{37} \mathrm{MYR}\right)$ on (A) body weight, (B) food intake, (C) non-fasting plasma glucose and (D) non-fasting plasma insulin in $o b / o b$ mice. Parameters were measured prior to and 24 days during treatment with GIP 
peptides $(25 \mathrm{nmol} / \mathrm{kg}$ body weight) or saline vehicle $(0.9 \%(\mathrm{w} / \mathrm{v}) \mathrm{NaCl})$. Data are expressed as mean \pm SEM for 8 mice. ${ }^{*} \mathrm{p}<0.05, * * \mathrm{p}<0.01, * * * \mathrm{p}<0.001$ compared to saline-treated group. ${ }^{\Delta} \mathrm{p}<0.05,{ }^{\Delta \Delta} \mathrm{p}<0.01,{ }^{\Delta \Delta \Delta} \mathrm{p}<0.001$ compared with $N$-AcGIP-treated mice. $\square$, saline vehicle; $\boldsymbol{\Delta}$, $N$-AcGIP; $\mathbf{\square}, \operatorname{GIP}\left(\mathrm{Lys}^{37} \mathrm{MYR}\right) ; \nabla, N$-AcGIP(Lys $\left.{ }^{37} \mathrm{MYR}\right)$.

Fig. 7 - Effects of daily administration of $N$-AcGIP, GIP(Lys $\left.{ }^{37} \mathrm{MYR}\right)$ and $N$-AcGIP(Lys $\left.{ }^{37} \mathrm{MYR}\right)$ on (A) glucose tolerance and (B) plasma insulin response to glucose in $o b / o b$ mice. Tests were conducted after daily treatment with GIP peptides ( $25 \mathrm{nmol} / \mathrm{kg}$ body weight) or saline vehicle $(0.9 \%(\mathrm{w} / \mathrm{v}) \mathrm{NaCl})$ for 24 days. Glucose $(18 \mathrm{mmol} / \mathrm{kg}$ body weight; ip) was administered at time $\mathrm{t}=0$. Plasma glucose and insulin AUC values for 0-180 min post injection are also included. Data are expressed as mean \pm SEM for 8 mice. ${ }^{* *} \mathrm{p}<0.01,{ }^{* * *} \mathrm{p}<0.001$ compared to saline-treated group. ${ }^{\Delta} \mathrm{p}<0.05,{ }^{\Delta \Delta} \mathrm{p}<0.01,{ }^{\Delta \Delta \Delta} \mathrm{p}<0.001$ compared with $N$-AcGIP-treated mice. $\square$, saline vehicle; $\boldsymbol{\Delta}, N$-AcGIP; $\mathbf{-}$ GIP(Lys ${ }^{37}$ MYR $) ; \nabla, N$-AcGIP(Lys ${ }^{37}$ MYR $)$. 


\section{Figure 1}

1

2

3

4

5

6
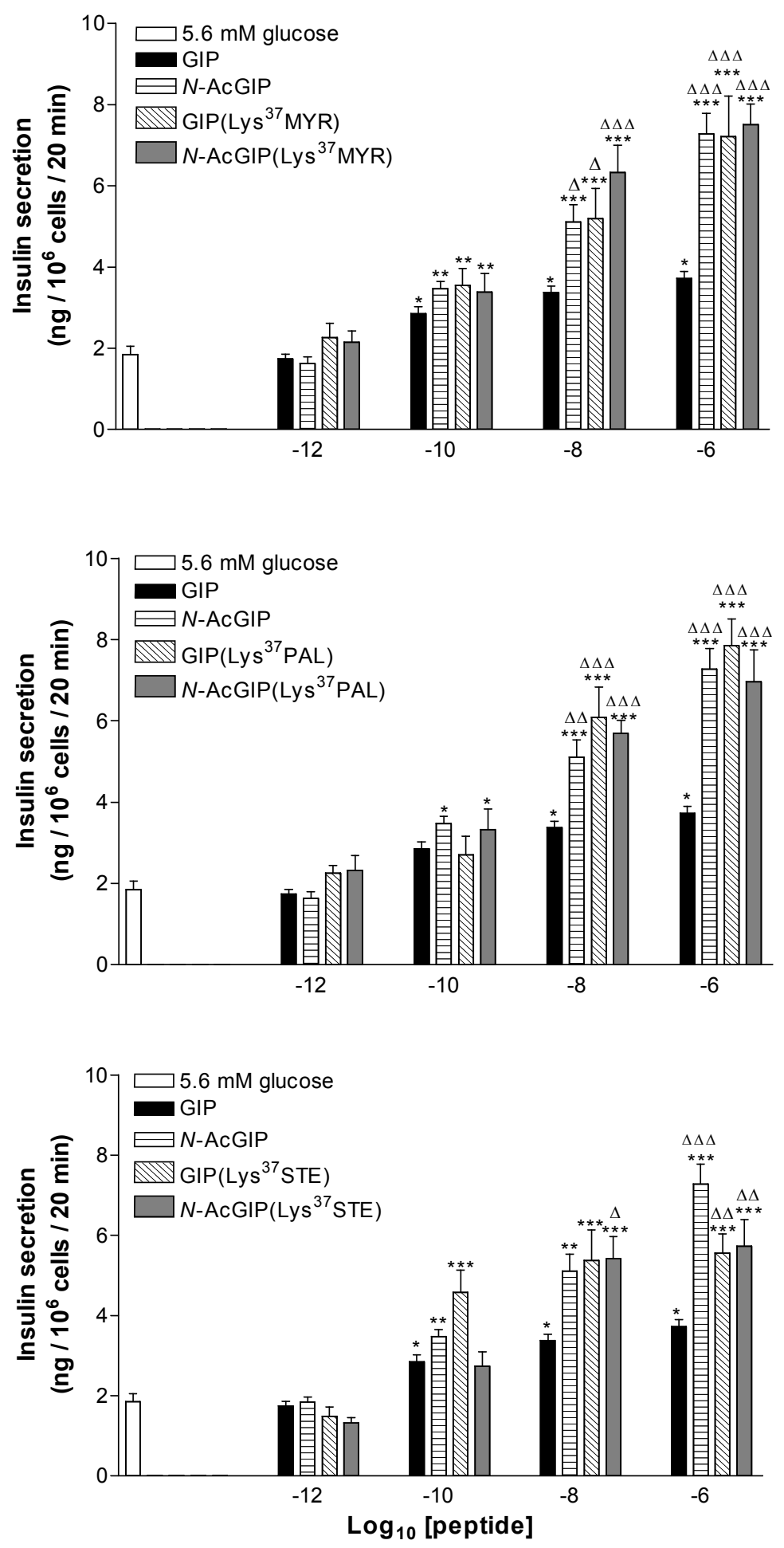


\section{Figure 2}

1

2

3

4

5

6

8

10

11

12

13

14

15

16

17

18

19

20

21

22

23

24

25

26

27

28

29

30

31

32

33

34

35

36

37

38

39

40

41

42

43

44

45

46

47

48

49

50

51

52

53

54

55

56

57

58

59

60

61

62

63

64

65
A
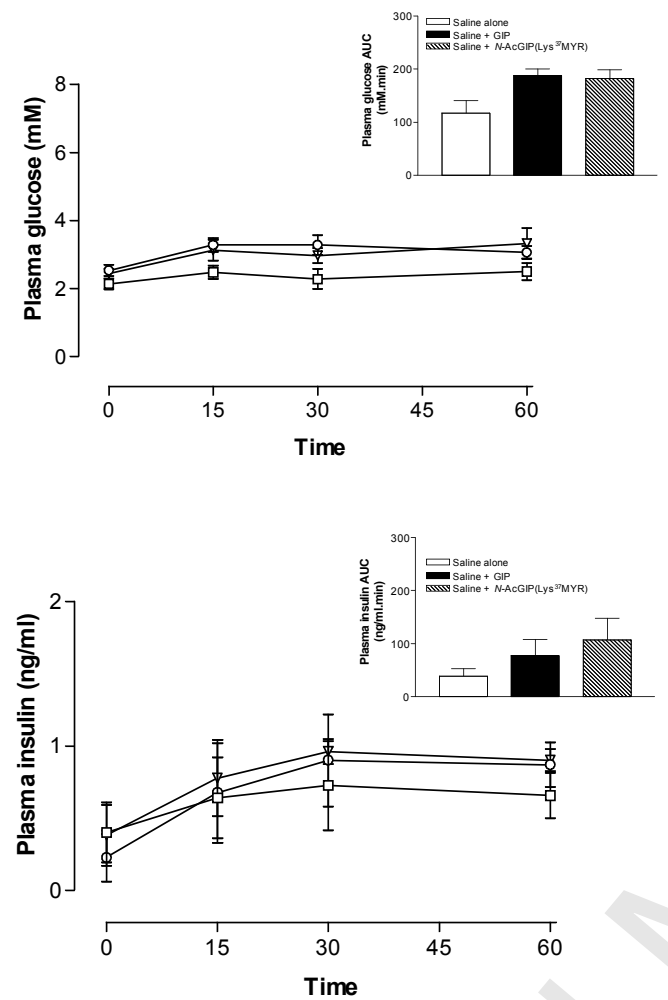

B
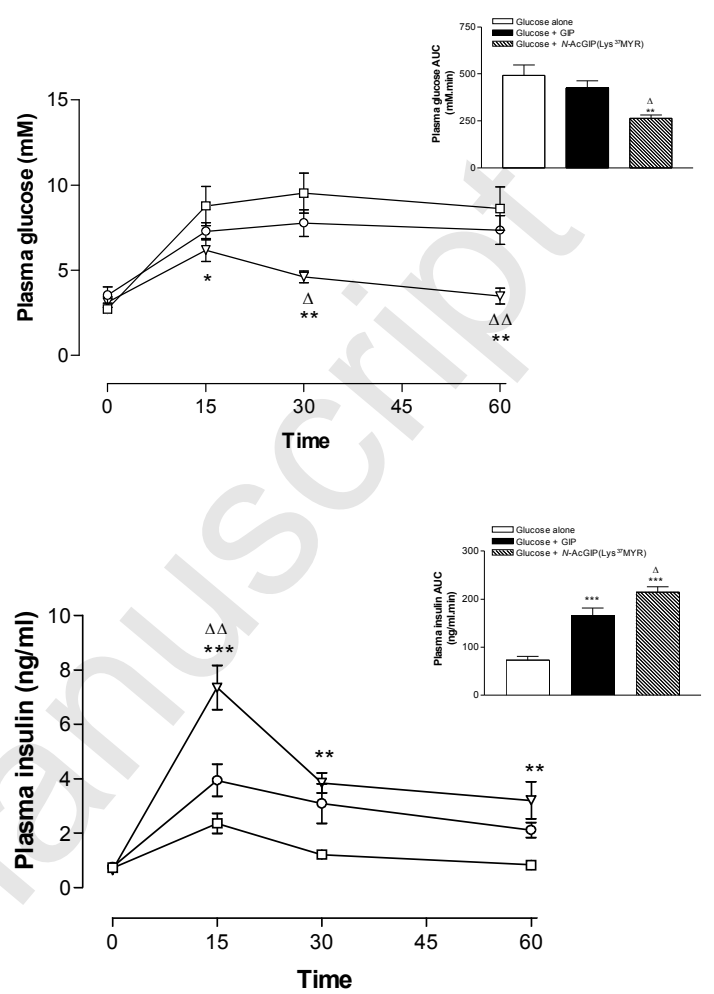


\section{Figure 3}

1

2

3

4

5

6

7

8

10

11

12

13

14

15

16

17

18

19

20

21

22

23

24

25

26

27

28

29

30

31

32

33

34

35

36

37

38

39

40

41

42

43

44

45

46

47

48

49

50

51

52

53

54

55

56

57

58

59

60

61

62

63

64

65
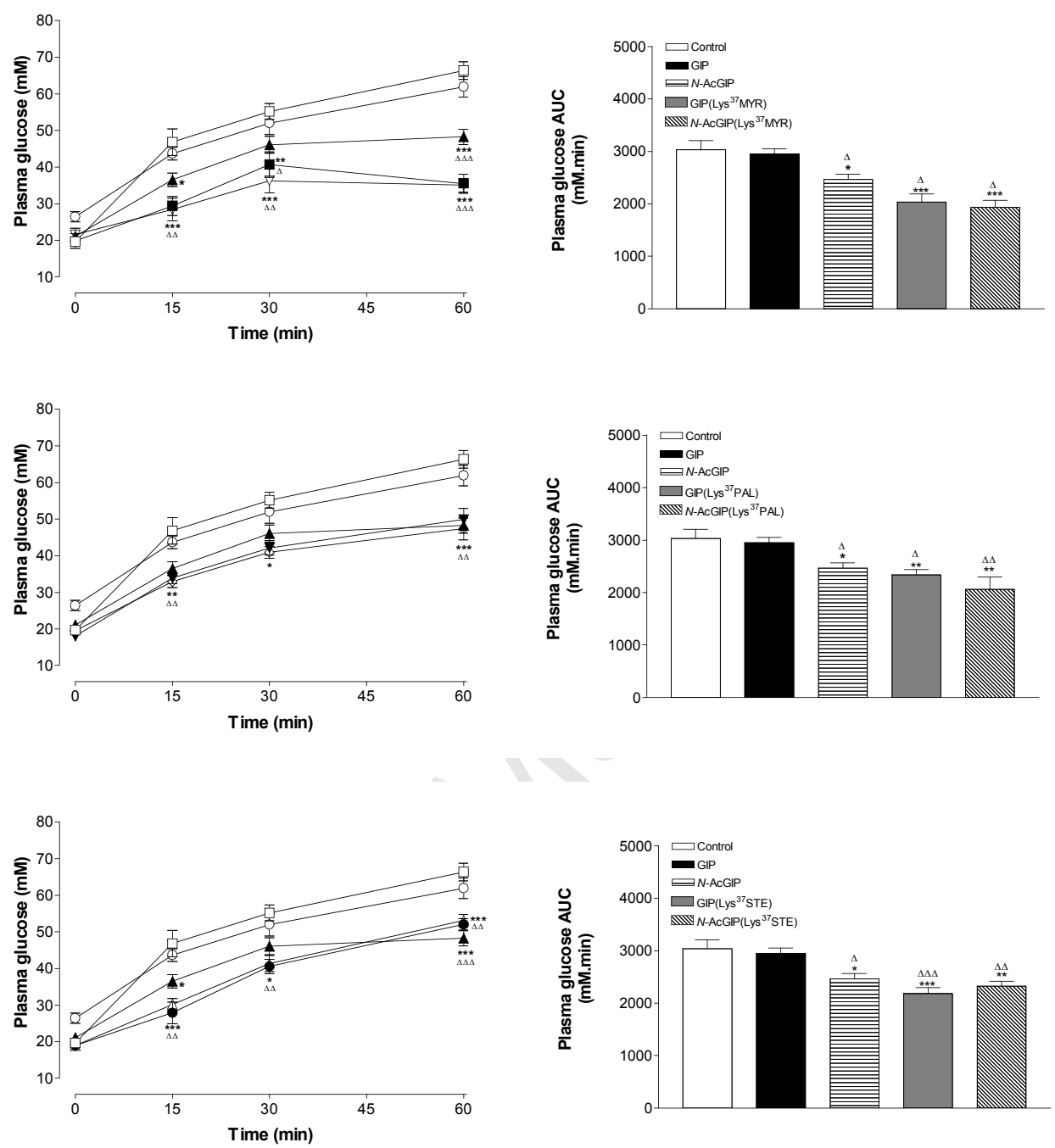


\section{Figure 4}

1

2

3

4

5

6

7

8

10

11

12

13

14

15

16

17

18

19

20

21

22

23

24

25

26

27

28

29

30

31

32

33

34

35

36

37

38

39

40

41

42

43

44

45

46

47

48

49

50

51

52

53

54

55

56

57

58

59

60

61

62

63

64

65
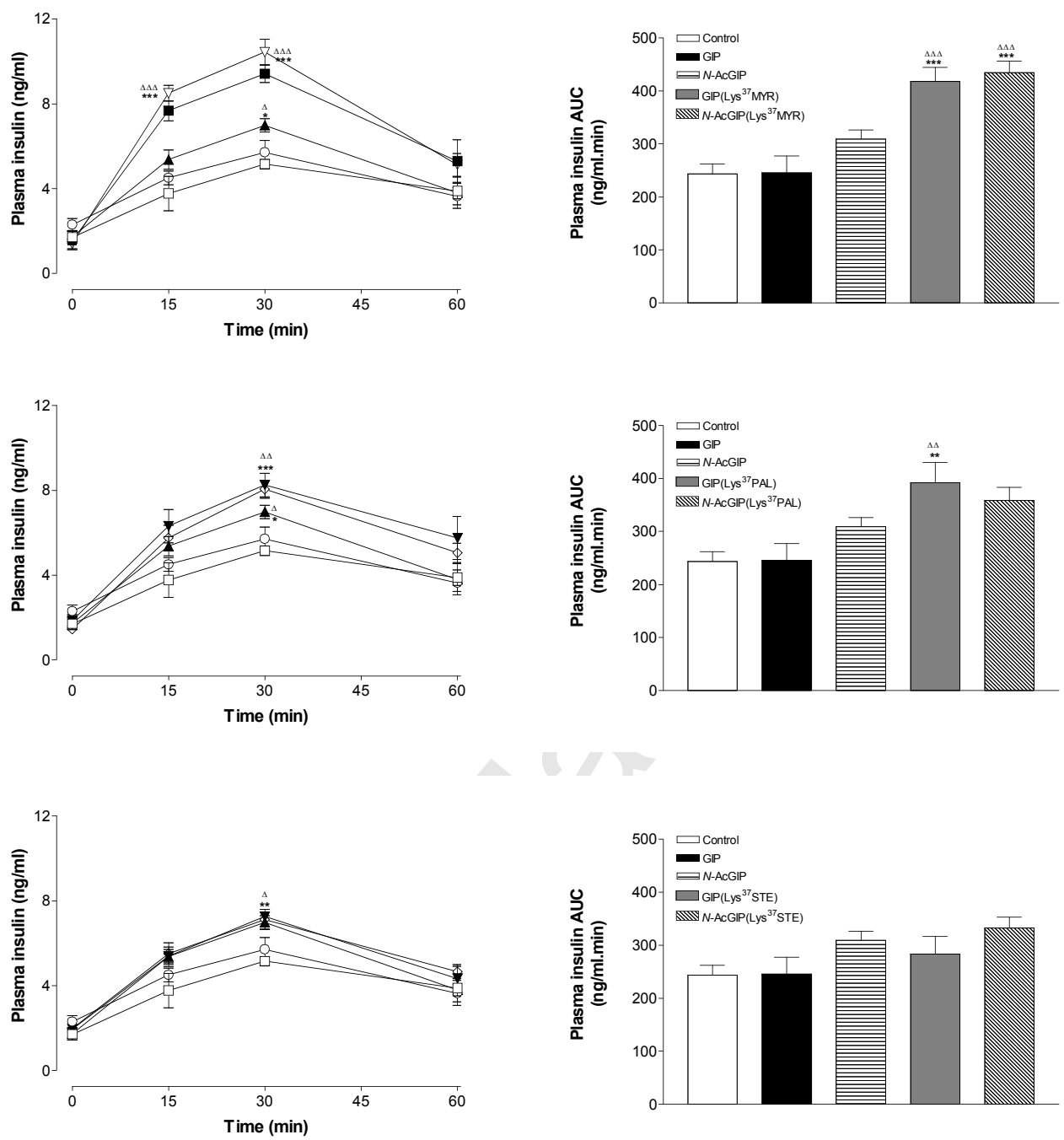


\section{Figure 5}

1

2

3

4

5

6

7

8

10

11

12

13

14

15

16

17

18

19

20

21

22

23

24

25

26

27

28

29

30

31

32

33

34

35

36

37

38

39

40

41

42

43

44

45

46

47

48

49

50

51

52

53

54

55

56

57

58

59

60

61

62

63

64

65
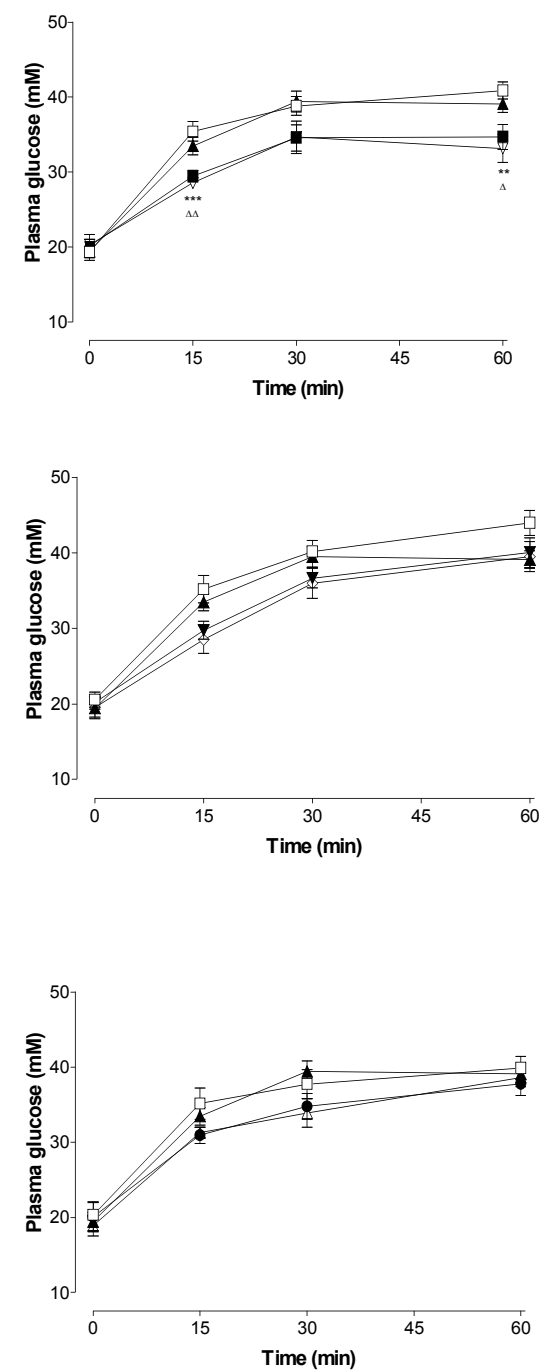
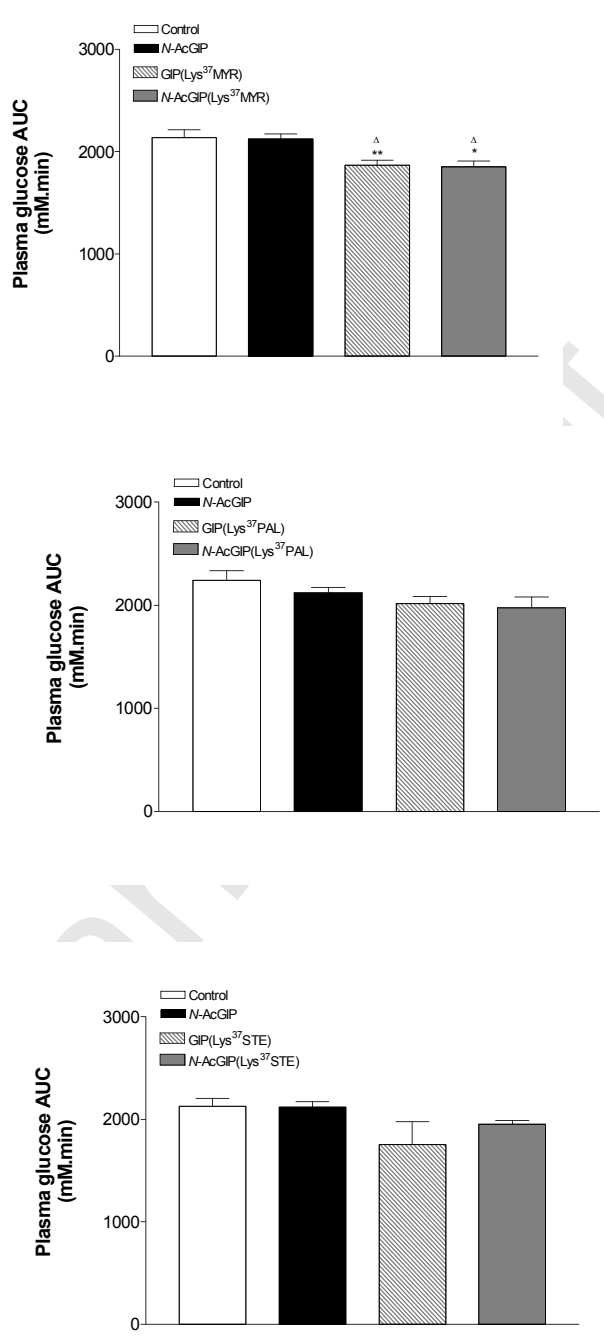


\section{Figure 6}
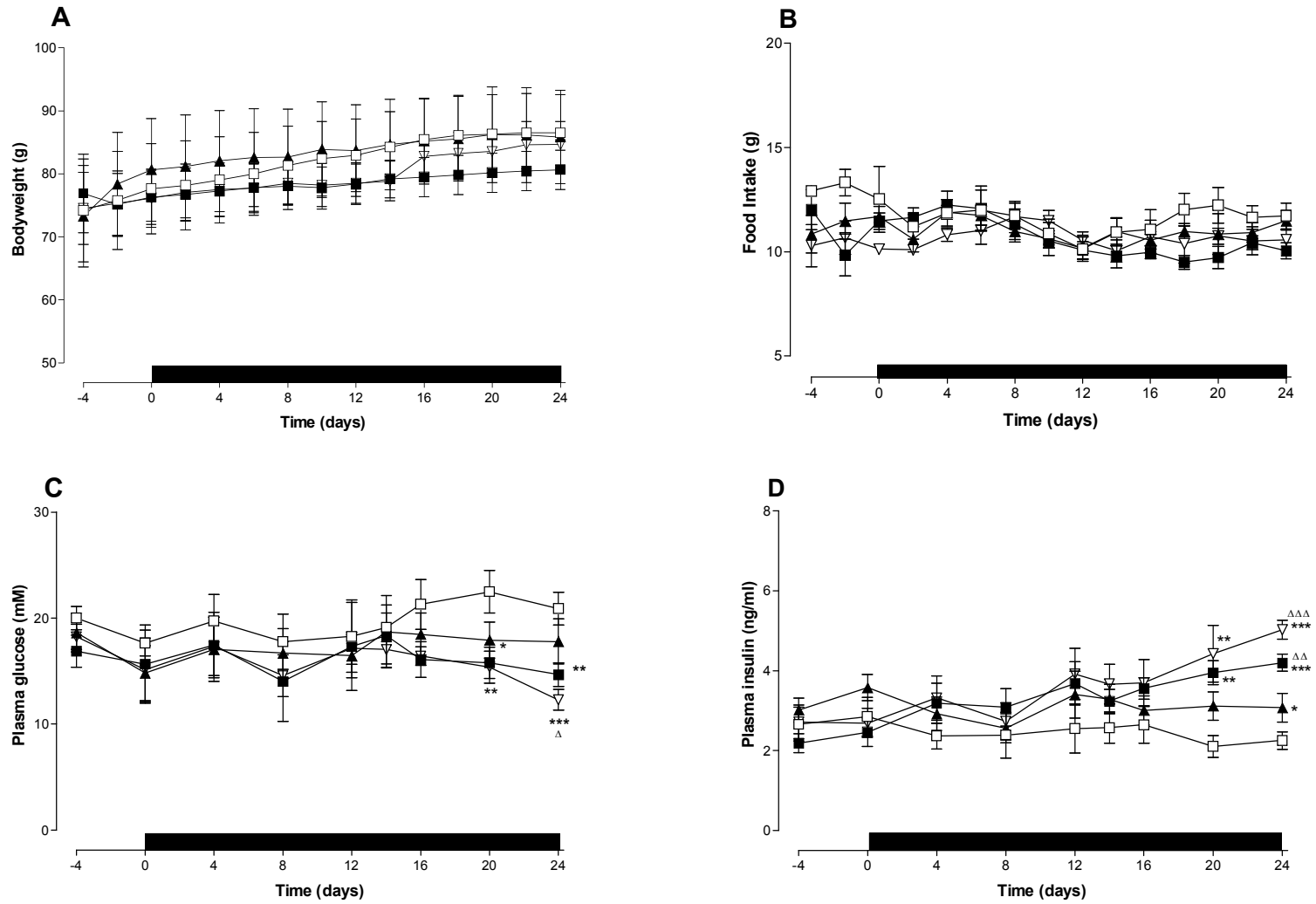


\section{Figure 7}

1

2

3

4

5

6

7

8

10

11

12

13

14

15

16

17

18

19

20

21

22

23

24

25

26

27

28

29

30

31

32

33

34

35

36

37

38

39

40

41

42

43

44

45

46

47

48

49

50

51

52

53

54

55

56

57

58

59

60

61

62

63

64

65
B
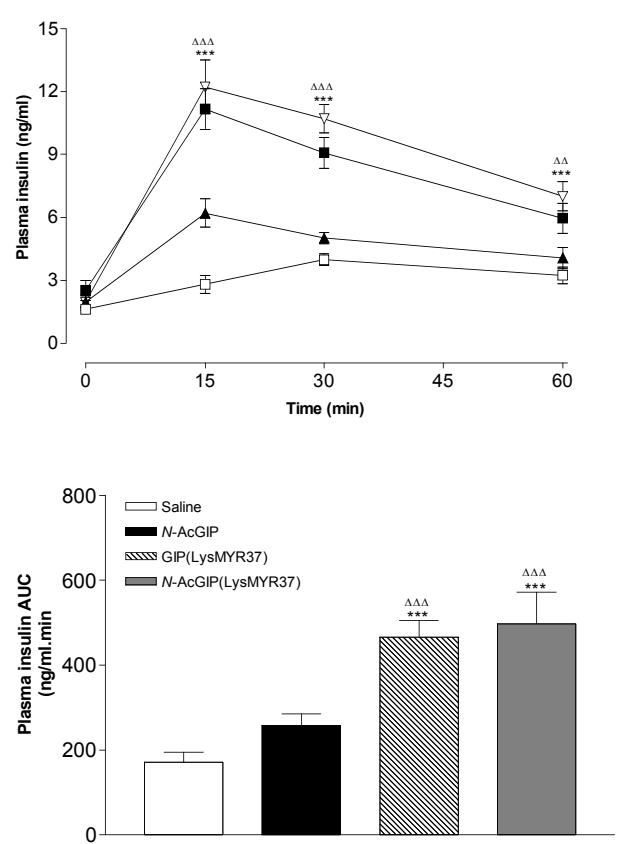
Table 1 In vitro characteristics of GIP peptides with and without N-terminal acetylation

\begin{tabular}{|l|c|c|c|c}
\hline \multirow{2}{*}{ Peptide } & \multicolumn{2}{|c|}{ MALDI-TOF MS } & $\begin{array}{c}\text { Estimated } \\
\text { half-life (h) }\end{array}$ & $\begin{array}{c}\text { cAMP EC } \\
\text { (nM) }\end{array}$ \\
\cline { 2 - 3 } & $\begin{array}{c}\text { Theoretical } \\
\text { (Da) }\end{array}$ & $\begin{array}{c}\text { Experimental } \\
\text { (Da) }\end{array}$ & & \\
\hline GIP & 4982.4 & 4982.2 & 2.2 & $0.70 \pm 0.40$ \\
\hline$N$-AcGIP & 5023.0 & 5022.2 & $>24$ & $0.17 \pm 0.01$ \\
\hline GIP(Lys ${ }^{37}$ MYR) & 5192.8 & 5194.2 & $>24$ & $0.27 \pm 0.03$ \\
\hline$N$-AcGIP(Lys ${ }^{37}$ MYR) & 5235.8 & 5236.4 & $>24$ & $0.07 \pm 0.01$ \\
\hline GIP(Lys ${ }^{37}$ PAL) & 5218.0 & 5219.1 & $>24$ & $0.07 \pm 0.03$ \\
\hline$N$-AcGIP(Lys $\left.{ }^{37} \mathrm{PAL}\right)$ & 5264.0 & 5263.3 & $>24$ & $0.11 \pm 0.03$ \\
\hline GIP(Lys ${ }^{37}$ STE) & 5247.0 & 5249.8 & $>24$ & $0.08 \pm 0.02$ \\
\hline$N$-AcGIP(Lys $\left.{ }^{37} \mathrm{STE}\right)$ & 5290.0 & 5292.8 & $>24$ & $0.09 \pm 0.01$ \\
\hline
\end{tabular}

MALDI-TOF MS: purified peptide samples were mixed with $\alpha$-cyano- 4 hydroxycinnamic acid, applied to the sample plate of a Voyager-DE BioSpectrometry Workstation and mass-to-charge $(\mathrm{m} / \mathrm{z})$ ratio $v s$ relative peak intensity recorded. DPP-IV degradation: resistance of GIP and GIP analogues to degradation by DPP-IV was measured $(n=4)$ following $0,2,4,8$ and $24 \mathrm{~h}$ incubations. Reaction products were subsequently analysed by HPLC and degradation calculated as a percentage of intact peptide relative to the major degradation fragment, GIP(3-42). cAMP production: $\mathrm{EC}_{50}$ values calculated are expressed as mean $\pm \mathrm{SEM}$ of at least 3 independent experiments. 
Table 2 Effects of daily administration of $N$-AcGIP, GIP(Lys ${ }^{37}$ MYR) and $N$-GIP(Lys ${ }^{37}$ MYR) on insulin sensitivity, insulin content and circulating triglycerides in $o b / o b$ mice.

\begin{tabular}{|l|c|c|c|}
\hline Peptide treatment & $\begin{array}{c}\text { Insulin sensitivity } \\
\text { (glucose AUC) }\end{array}$ & $\begin{array}{c}\text { Insulin content (ng/g } \\
\text { tissue) }\end{array}$ & Triglycerides (ng/dl) \\
\hline Saline vehicle & $898.7 \pm 80.0$ & $3.9 \pm 0.4$ & $2.2 \pm 0.2$ \\
\hline$N$-AcGIP & $997.5 \pm 72.6$ & $4.0 \pm 0.3$ & $2.1 \pm 0.3$ \\
\hline GIP(Lys ${ }^{37}$ MYR) & $912.0 \pm 34.2$ & $4.0 \pm 0.4$ & $2.4 \pm 0.3$ \\
\hline$N$-GIP(Lys ${ }^{37}$ MYR) & $902.3 \pm 95.9$ & $4.5 \pm 0.5$ & $2.1 \pm 0.2$ \\
\hline
\end{tabular}

Insulin sensitivity: exogenous insulin ( $50 \mathrm{U} / \mathrm{kg}$ body weight; ip) was administered after daily treatment with GIP peptides ( $25 \mathrm{nmol} / \mathrm{kg}$ body weight) for 24 days. Plasma glucose AUC values for 0-60 min post injection were calculated. Pancreatic insulin content and circulating triglycerides: parameters were measured after daily treatment with GIP peptides for 24 days. Data are expressed as mean \pm SEM for 8 mice. 
Figure 1
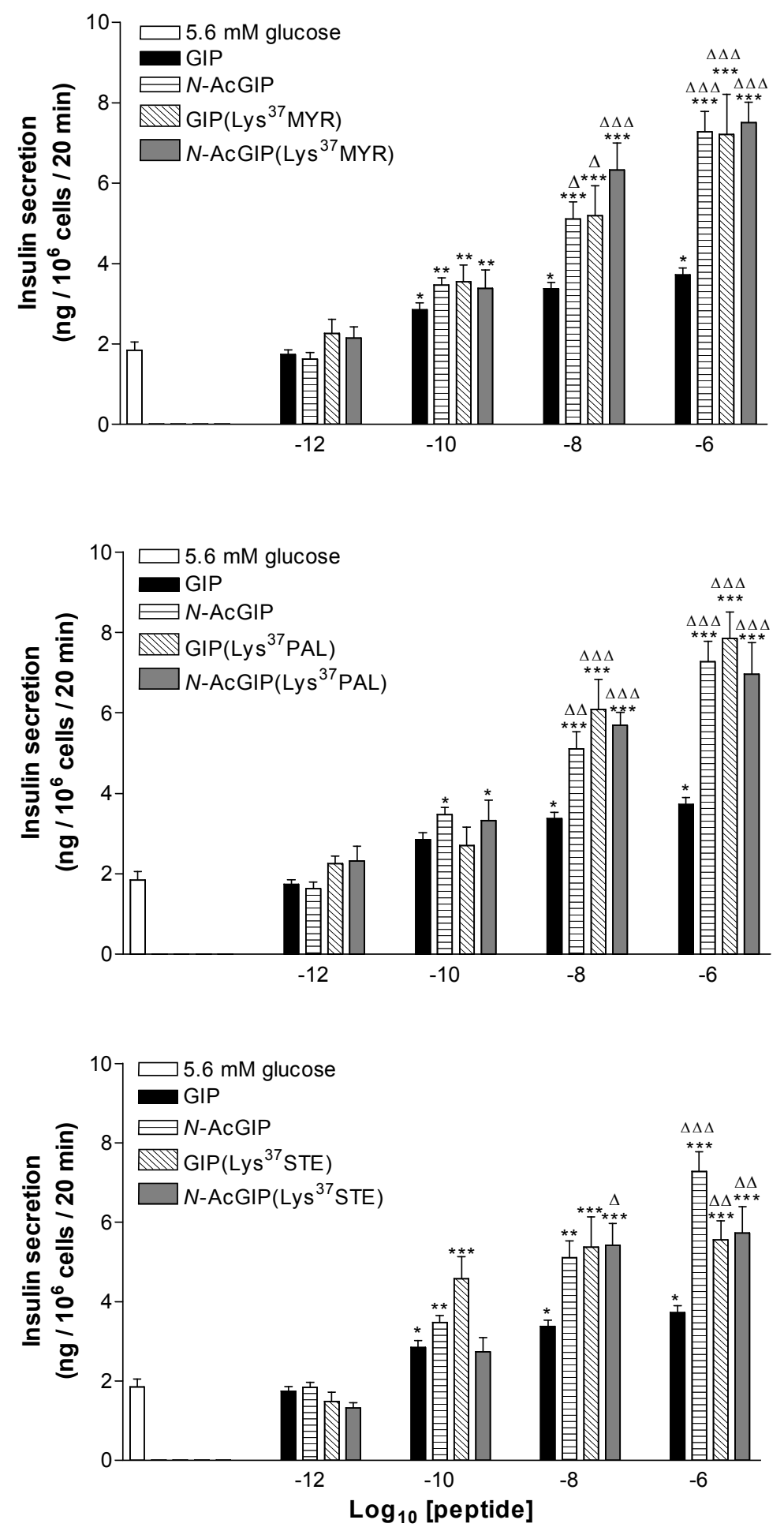


\section{Figure 2}

A
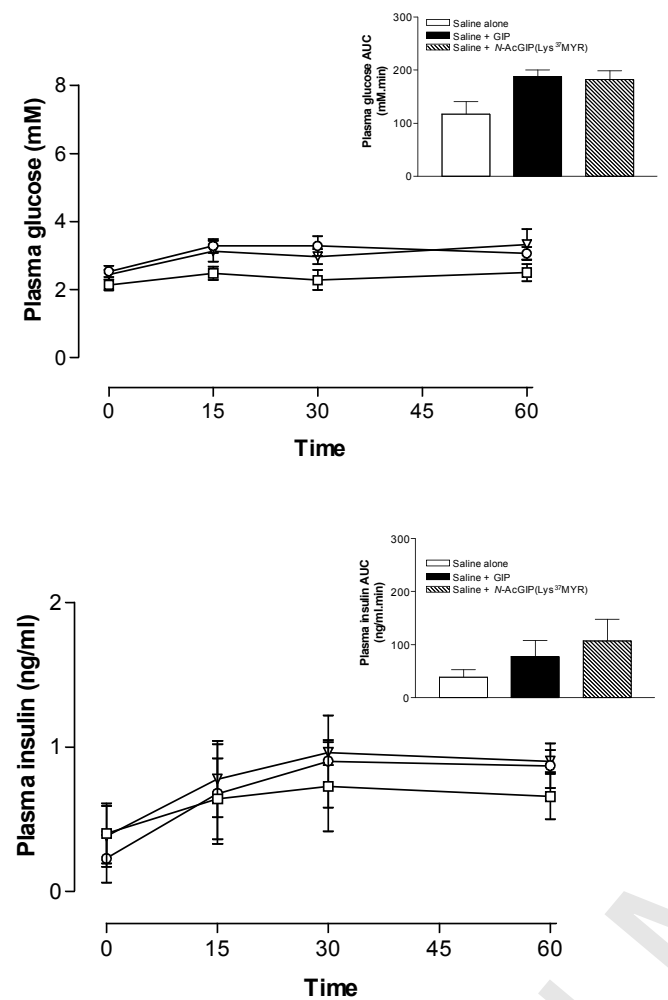

B
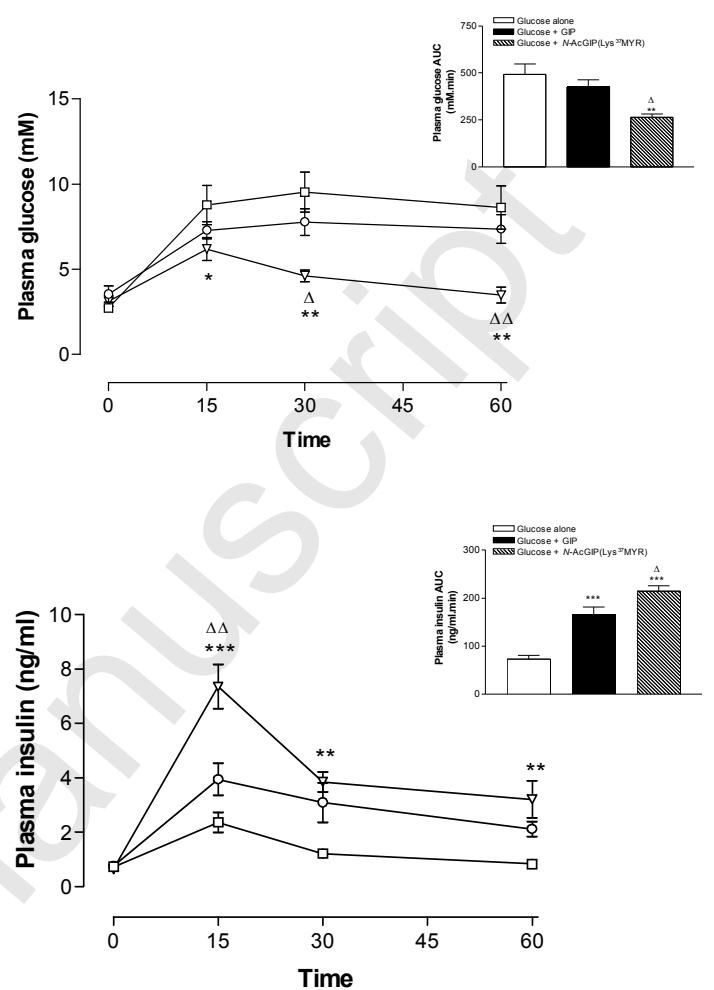


\section{Figure 3}
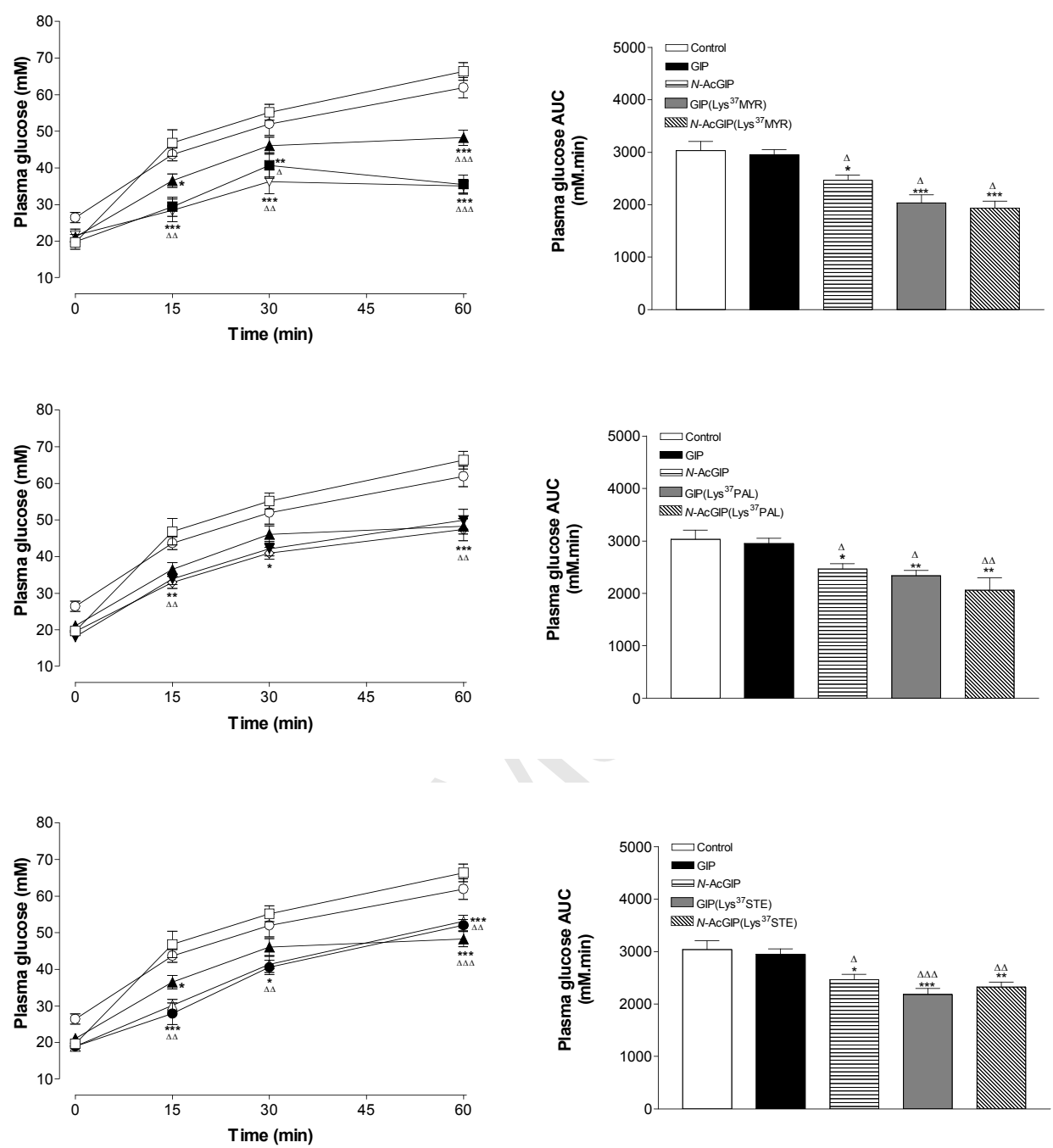


\section{Figure 4}
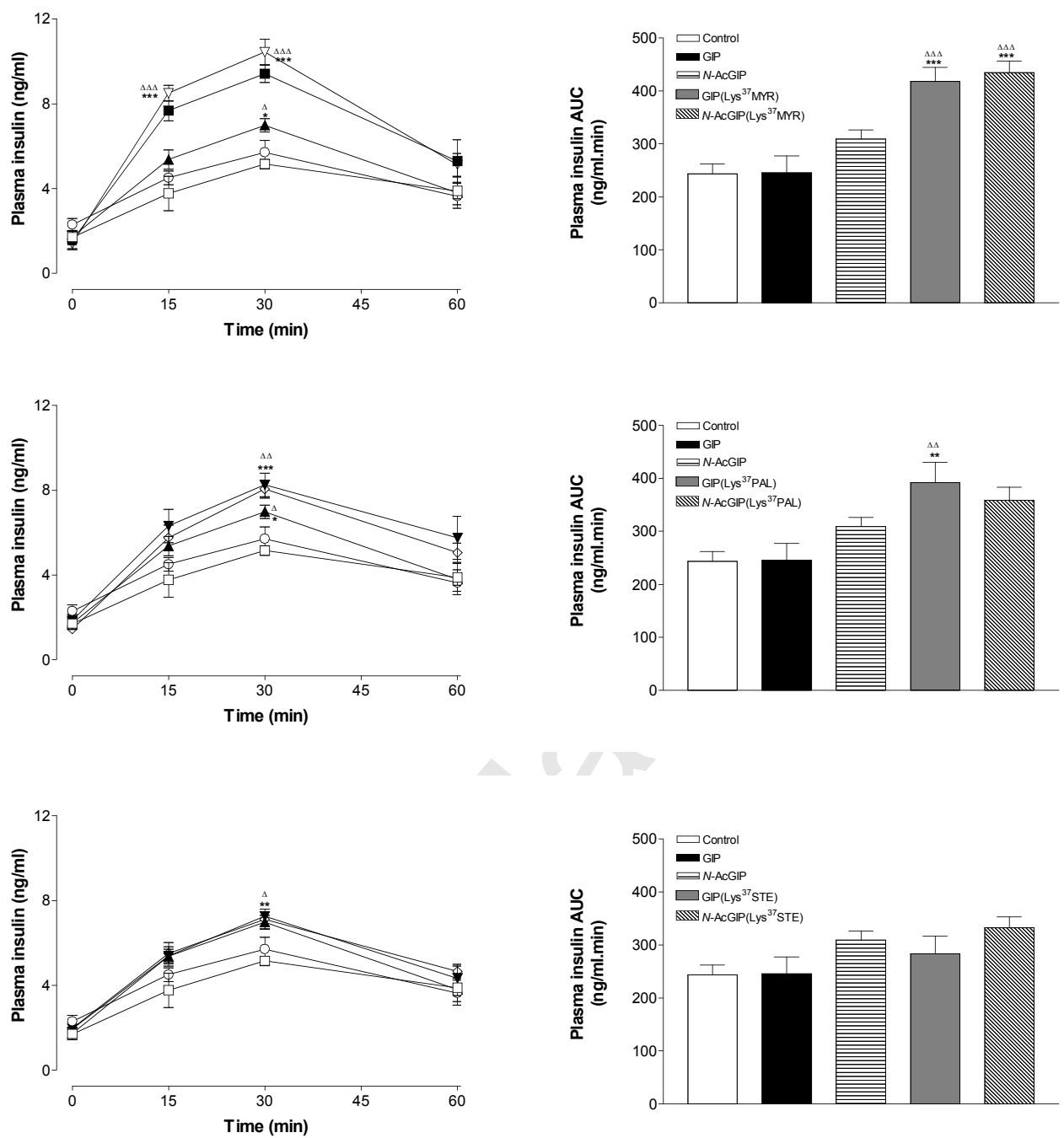


\section{Figure 5}
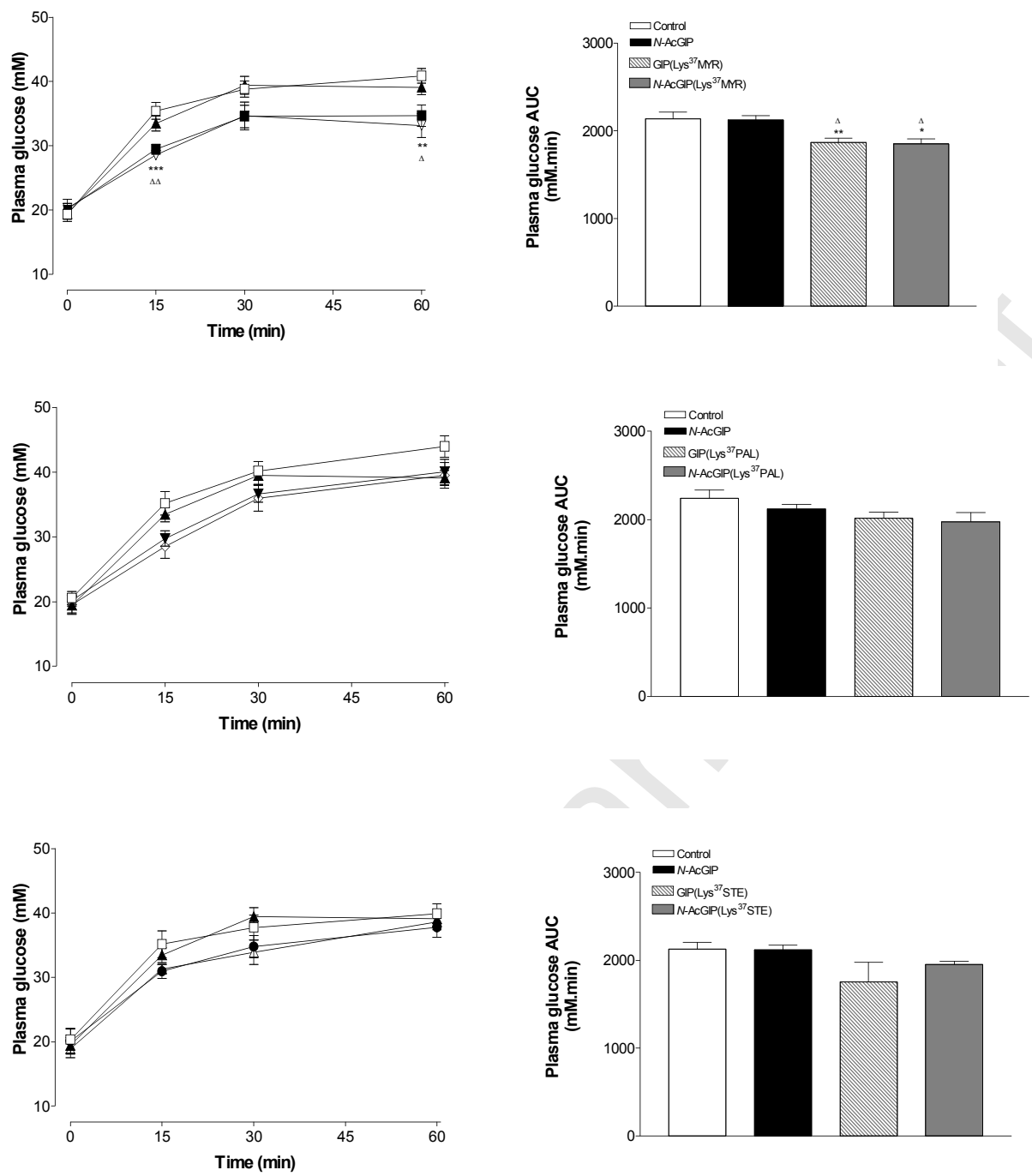


\section{Figure 6}
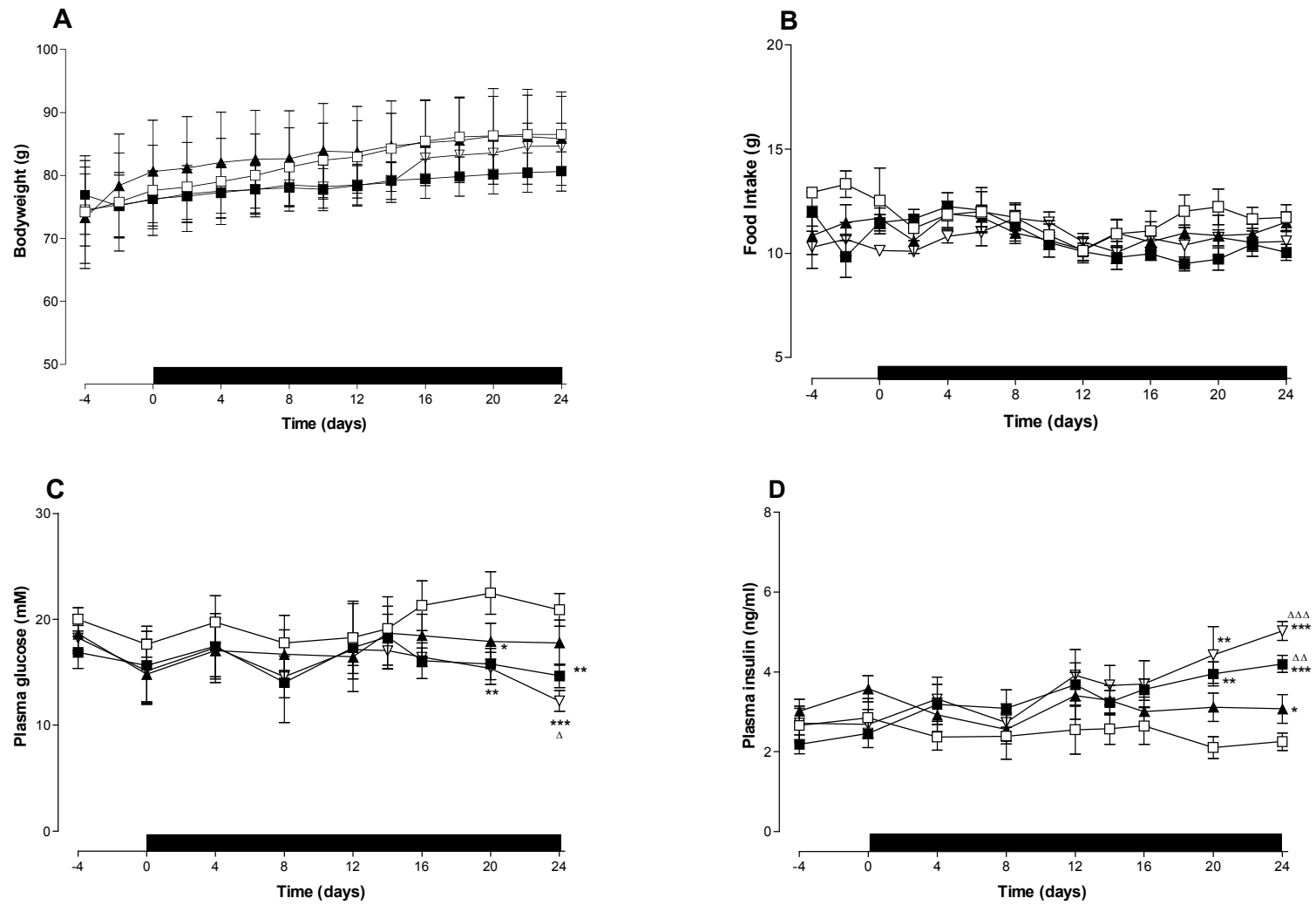


\section{Figure 7}

A
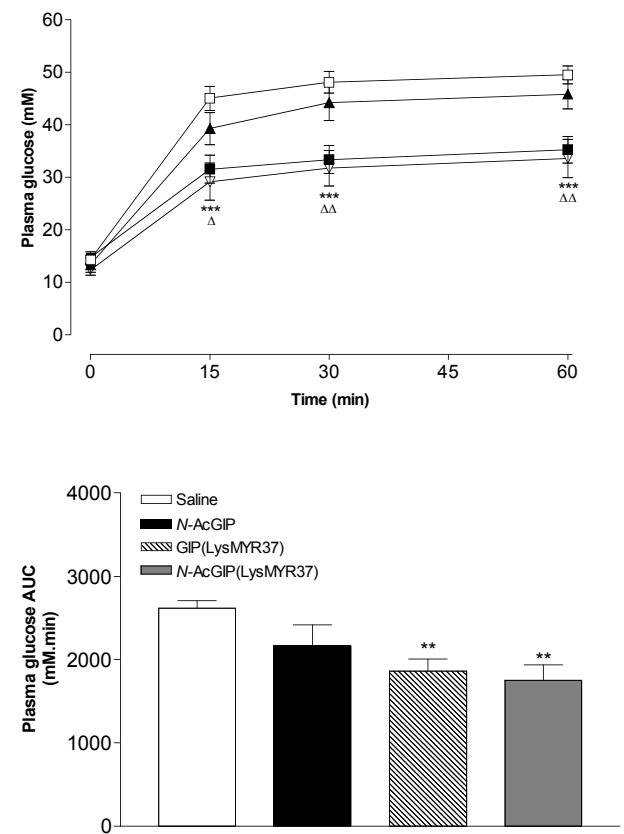

B
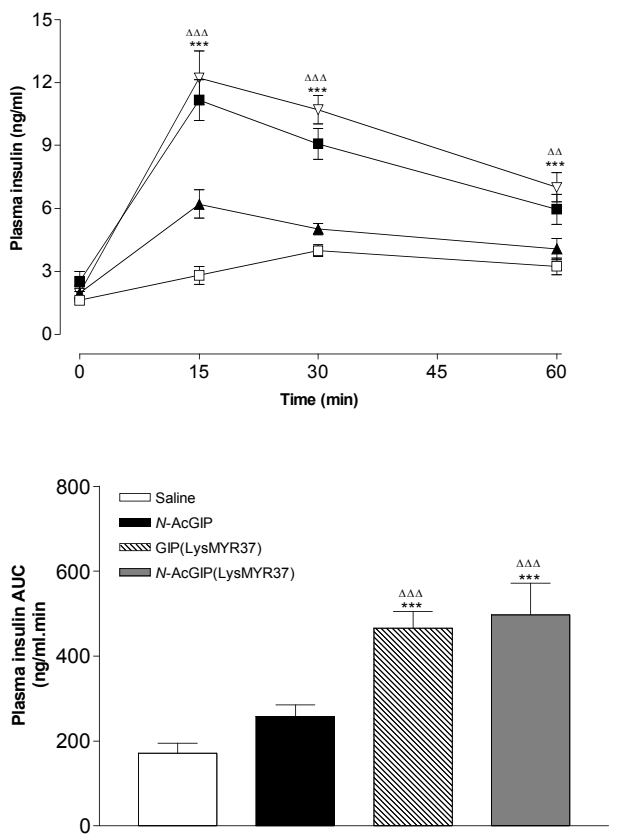


\section{Graphical Abstract}

C-terminal acylation particularly with myristic acid provides a class of stable, longer-acting forms of GIP for evaluation in diabetes therapy

1

10

20

30

40

$\mathrm{NH}_{2}$-YAEGTFISDYSIAMDKIHQQDFVNWLLAQKGKKNDWKHNITQ-COOH

$<$ represents: myristic, palmitic or stearic acid<smiles>CCCC</smiles>

Albumin 